Review

\title{
Impact of Molecular Technologies on Faba Bean (Vicia faba L.) Breeding Strategies
}

Annathurai Gnanasambandam ${ }^{1}$, Jeff Paull ${ }^{2}$, Ana Torres ${ }^{3}$, Sukhjiwan Kaur ${ }^{4}$, Tony Leonforte

${ }^{1}$, Haobing $\mathrm{Li}^{1}$, Xuxiao Zong ${ }^{5}$, Tao Yang ${ }^{5}$ and Michael Materne ${ }^{1, *}$

1 Department of Primary Industries, Biosciences Research Division, Grains Innovation Park, Private Bag 260, Horsham, Victoria 3401, Australia;

E-Mails: Annathurai.Gnanasambandam@dpi.vic.gov.au (A.G.);

Tony.Leonforte@dpi.vic.gov.au (T.L.); Haobing.Li@dpi.vic.gov.au (H.L.)

2 School of Agriculture, Food and Wine, The University of Adelaide, Waite Campus, Glen Osmond, South Australia 5064, Australia; E-Mail: jeffrey.paull@adelaide.edu.au

3 IFAPA, Centre Alameda del Obispo, Breeding and Biotechnology Area, Apdo. 3092, Córdoba E14080, Spain; E-Mail: anam.torres.romero@juntadeandalucia.es

4 Department of Primary Industries, Biosciences Research Division, VABC, 1 Park Drive, Bundoora, Victoria 3083, Australia; E-Mail: Sukhjiwan.Kaur@dpi.vic.gov.au

5 Institute of Crop Sciences (ICS), Chinese Academy of Agricultural Sciences (CAAS),

12 Zhong Guan Cun South Street, Haidian District, Beijing 100081, China;

E-Mails: zongxx@mail.caas.net.cn (X.Z.); taoyang@caas.net.cn (T.Y.)

* Author to whom correspondence should be addressed; E-Mail: Michael.Materne@dpi.vic.gov.au; Tel.: +61-3-5362-2312; Fax: +61-3-5362-2317.

Received: 10 May 2012; in revised form: 3 June 2012 / Accepted: 4 June 2012 /

Published: 4 July 2012

Abstract: Faba bean (Vicia faba L.) is a major food and feed legume because of the high nutritional value of its seeds. The main objectives of faba bean breeding are to improve yield, disease resistance, abiotic stress tolerance, seed quality and other agronomic traits. The partial cross-pollinated nature of faba bean introduces both challenges and opportunities for population development and breeding. Breeding methods that are applicable to self-pollinated crops or open-pollinated crops are not highly suitable for faba bean. However, traditional breeding methods such as recurrent mass selection have been established in faba bean and used successfully in breeding for resistance to diseases. Molecular breeding strategies that integrate the latest innovations in genetics and genomics with traditional breeding strategies have many potential applications for future faba bean 
cultivar development. Hence, considerable efforts have been undertaken in identifying molecular markers, enriching genetic and genomic resources using high-throughput sequencing technologies and improving genetic transformation techniques in faba bean. However, the impact of research on practical faba bean breeding and cultivar release to farmers has been limited due to disconnects between research and breeding objectives and the high costs of research and implementation. The situation with faba bean is similar to other small crops and highlights the need for coordinated, collaborative research programs that interact closely with commercially focused breeding programs to ensure that technologies are implemented effectively.

Keywords: biotic stress; abiotic stress; traditional breeding; molecular markers; marker-assisted selection; molecular breeding; genomics

\section{Introduction}

Faba bean (Vicia faba L.), also referred to as the broad bean, fava bean, horse bean or field bean, is a major food and feed legume. It is a crucial source of protein in food, especially in Mediterranean countries and China and its seeds have high nutritional value [1]. The 2010 world production of faba beans was $4.3 \mathrm{Mt}$ from $2.55 \mathrm{Mha}$, which is relatively small compared with soybean and pea world production (262 Mt and $10 \mathrm{Mt}$, respectively) [2].

The major objectives of faba bean breeding programs are similar to other crops and include yield, resistance/tolerance to biotic and abiotic stresses, adaptation to the target environment, appropriate phenology, plant growth habit, seed quality and traits to enhance crop management. The two major methods of faba bean breeding are population improvement with cycles of recurrent selection, and treating faba bean as a self-pollinated crop and accepting a degree of cross-pollination between breeding lines. Traditional faba bean breeding involves crossing elite parents, multi-stage testing of progeny, identify progeny that outperform the parents for specific traits and the release of superior varieties. Typically this process could take up to 10 years to release a commercial cultivar. Development and advancement of new plant molecular biology techniques and genomic tools could assist conventional breeding to accelerate the release of faba bean cultivars.

Due to the potential of using molecular tools for faba bean cultivar development, significant efforts have been made in the last two decades to understand the genetics and genomics of faba bean. Linkage maps of faba bean have been constructed based on RFLPs (Restriction Fragment Length Polymorphisms), RAPDs (Random Amplified Polymorphic DNA), ITAPs (Intron-Targeted Amplified Polymorphisms) and SSRs (Simple Sequence repeats) [3-8], and various QTLs (Quantitative Trait Loci) have been identified [9]. Recently, markers linked to growth habit and nutritional value of faba bean seeds have been identified [10-14]. Further efforts are being made to identify molecular markers linked to biotic and abiotic stress tolerances.

In this paper, we discuss the progress and prospects of traditional faba bean breeding including the challenges and opportunities and breeding for specific target traits. We then discuss the progress and prospects for molecular faba bean breeding including the marker-assisted selection and use of genomic 
technologies. We also discuss some potential impact of the molecular and genomic technologies on future faba bean crop improvement.

\section{Origin and Germplasm Resources}

Faba bean was one of the earliest crops to be domesticated. The origin of the crop is thought to be in the Near East, and remnant seed dating to the 10th Millennium before present (BP) has been identified in northern Syria [15]. It subsequently spread to Europe, North Africa and China and has been cultivated in each of these regions for millennia [16]. It was introduced to South America by the Spanish and was established as a crop in Australia in the 1980s [17]. The Australian faba bean breeding program started in the 1970s and for many years relied on introduced germplasm. Germplasm with best adaptation in southern Australia originated from the Mediterranean Basin and was the basis for the commercial varieties Fiord and Fiesta. In recent years, hybridisation among very diverse germplasm has been undertaken and elite breeding lines developed that include parents with very poor adaptation in Australia. This has demonstrated the benefit of including germplasm from different origins in the breeding program and might be an indicator of heterosis from inter-pool crossing.

Faba bean is now cultivated over a latitudinal range from the Equator to approximately $50{ }^{\circ} \mathrm{N}$ and $40{ }^{\circ} \mathrm{S}$ and altitude range from sea level to above $3000 \mathrm{~m}$. The long period of cultivation across very diverse environments has resulted in differentiation of germplasm into distinct groups based on seed size (viz. subspecies paucijuga, minor, equina and major) and region of adaptation (e.g., Winter, Spring and Mediterranean types). While modern varieties dominate in Australia, Europe and Canada, traditional landraces are still widely grown in many countries and a mix of traditional and modern varieties are grown in other countries.

\section{Traditional Breeding: Progress and Prospects}

\subsection{Challenges and Opportunities}

Faba bean differs from other cool season pulse crops in two significant ways:

(i) $V$. faba is reproductively isolated from all other species and its progenitor species is not known. Hence, the genetic resources available for crop improvement are restricted to the cultivated species. Though there are a number of significant collections of faba bean germplasm (recently reviewed by [18]), further evaluation is required to identify the full extent of phenotypic variation within these collections. The most extensive characterisation of faba bean germplasm has been undertaken for disease resistance, while more restricted evaluation has been undertaken for several traits of local interest.

(ii) Faba bean is partially allogamous, or out-crossing, with the rate of out-crossing differing between environments and genotypes. As bee species are the major vectors for pollen transfer, the rate of cross-pollination varies across environments and with the population size of pollinators. Reported values for cross-pollination range from 10 to 70\% [19]. The mixed mating system means that breeding methods that are applied to self-pollinated crops are not suitable, or require modification, to be used for faba beans, while the intermediate level of cross-pollination limits the applicability of breeding methods that are used for highly out-crossed crops such as maize [20]. 
The partial cross-pollinated nature of faba bean introduces both challenges and opportunities for population development and multiplication.

(i) The level of cross-pollination within faba bean means that it is well suited for the development of synthetic varieties where a degree of heterosis can be maintained, although at a lower level than for $\mathrm{F}_{1}$ hybrid varieties. Heterosis for yield has been demonstrated [21] and hybrid faba bean varieties have been proposed. However, despite cytoplasmic male sterility systems being identified in faba bean [22,23], hybrid varieties are not yet available commercially, and are unlikely, due to the high cost of producing and growing very large seeds.

(ii) A major consequence of faba bean being partially cross-pollinated is that populations are highly heterogeneous and plants are heterozygous. Hence, there is considerable potential to select within populations for specific traits, as demonstrated by the development of the BPL (bean pure line) collection at ICARDA (International Center for Agricultural Research in the Dry Areas). Disease resistance was identified in many BPLs [24] indicating the potential of recurrent mass selection for population improvement in faba bean.

(iii) Screen houses are routinely used in the early generations, e.g., $F_{1}, F_{2}$ and $F_{3}$, of a breeding cycle to eliminate bees and thus prevent cross-pollination. During this phase, it is possible to undertake selection for traits with high heritability such as seed colour, plant habit, time of flowering and resistance to diseases such as ascochyta blight, rust and cercospora leaf spot. However, it is generally not logistically feasible to multiply subsequent generations in the absence of bees; hence, alternative methods are employed to minimise cross-pollination between breeding lines during the multiplication phase prior to yield evaluation. A barrier of an alternative crop that flowers at the same time as faba bean can be grown around the faba bean multiplication plots to attract bees and minimise cross pollination between the faba bean plots. Alternatively, if selection for major traits has been undertaken in the $F_{2}$ and $F_{3}$ generations, lines can be multiplied in blocks of similar types, or trait specific gene pools (e.g., all white flower plants, or all resistant to ascochyta blight), and any cross-pollination between lines will not compromise the major trait of the population. Elite individual lines selected through this process can either be developed as "pure line" commercial varieties or be combined with other elite lines as components of a synthetic cultivar.

\subsection{Breeding for Yield and Plant Morphological Traits}

Yield of faba bean is considered to be unreliable, often due to a major stress at a critical phase in crop development. Reliability of yield is addressed through appropriate phenology and improving resistance or tolerance to the dominant stresses in the target region. Faba bean varieties and breeding lines express a significant level of genotype $\times$ environment interaction for yield. This has been observed on a mega-scale, for example in Europe, where winter, spring and Mediterranean faba beans show very specific adaptation to particular regions $[25,26]$. In China, spring sown varieties from the northern provinces are very poorly adapted to the sub-tropical southern provinces [27] and in Australia, southern and northern varieties differ in the time to maturity and disease resistance. Interactions for yield are also regularly observed at a more local scale and across years. In the Australian faba bean breeding program, the evaluation sites are located within the major production areas and lines are selected for adaptation to the specific areas. 
A number of traits associated with plant morphology are important target traits in the breeding programs. Stem strength, or standing ability, is important to facilitate harvesting and also reduce the risk of disease that is associated with a lodged crop. The stiff-straw trait is controlled by a single recessive gene [28] and is widely used in faba bean breeding programs in Europe. The height of the lowest pod is important for crops that are mechanically harvested. Pod height is determined by time to flowering, angle of lateral branches and length of internodes. There is significant variation in degree of pod dehiscence, and indehiscent pods are required for mechanical harvesting. Flattened constricted pods reduce the potential for weather damage to seeds prior to harvest.

Conventionally the crop has an indeterminate growth, but for fresh market production determinate growth habit is sought to assure a uniform crop. Determinate faba bean plants are characterized by a terminal inflorescence after four to five flowering nodes, which results in a considerable reduction of plant height and lodging. The terminal inflorescence trait, conditioned by the recessive $t i$ gene, has been incorporated into a number of varieties and while these have low biomass production and lower yield potential than conventional varieties the synchronous pod development facilitates mechanical harvesting of vegetable broad beans such as cv. Retaca [29].

Faba bean is highly responsive to management practices such as time of sowing and sowing rate. These factors can affect plant yield, yield components [30,31] and disease development. Thus, an additional level of breeding objectives includes those targeted for specific crop management practices. For example, the evolution of direct drilling technology has enabled earlier sowing in some countries such as Australia. In Australia, there is a dichotomy between maximising yield potential through early sowing and the greater risk and severity of foliar fungal diseases for early sown crops. Similarly, in Europe, winter sown faba beans have higher yield potential than spring sown crops but are at greater risk of disease development. Disease resistant varieties, therefore, have the dual advantage of reducing disease per se, and enabling early sowing to maximise yield potential.

\subsection{Breeding for Resistance to Biotic Stresses}

Faba bean is affected by a range of biotic stresses, including foliar fungal diseases, soil borne pathogens, viruses, parasitic weeds, nematodes and bruchids. However, many are of minor or local importance and are not major objectives in breeding programs. Germplasm collections have been screened for resistance to a range of diseases and pests and the status of sources of resistance was recently summarised by [32].

Breeding is generally considered the most effective means of disease control. However, for a genetic approach to disease control to be effective, (i) a good understanding of the host $\times$ pathogen interaction is needed; (ii) a degree of resistance to the pathogen must be identified; and (iii) efficient and effective screening systems should be available that can process large populations. The decision of whether to adopt selection for resistance to a particular disease within a breeding program will depend on the impact of the disease, likelihood of success, cost and availability of alternative methods of control and the overall priority of resistance to the particular disease compared to all other breeding aims.

The three fungal diseases, chocolate spot (Botrytis fabae), ascochyta blight (Ascochyta fabae) and rust (Uromyces viciae-fabae) can lead to very significant loss in yield and seed quality if susceptible varieties are cultivated and disease is not managed effectively with regular application of fungicides. 
Resistance to one or more of these diseases is a high priority in most faba bean breeding programs globally. A good level of resistance, although not immunity, is available to ascochyta blight and rust. For ascochyta blight, both single major gene and polygenic modes of inheritance have been reported and disease scoring is complicated by environmental conditions and the occurrence of physiological specialization between pathogen isolates and host genotypes [24,33]. For rust, hypersensitive resistance has been described as an incomplete resistance associated with late-acting necrosis of the host tissue, resulting in a reduction of the infection type [34].

Faba bean populations may be heterogeneous in reaction to ascochyta blight or rust and it is possible to develop resistant lines through several cycles of single plant selection, with self-pollination. This method was used at ICARDA to develop ascochyta blight BPLs [35] and has also been used extensively in the Australian faba bean breeding program to identify new sources of resistance [36]. For example, the selection of plants resistant to ascochyta blight within the heterogeneous cv. Fiesta resulted in the release of the resistant cv. Farah from the Australian faba bean breeding program. A population of Fiesta was screened for resistance to ascochyta blight and resistant plants were retained and grown in a bee-proof screen house to ensure self pollination. These plants were progeny tested and resistant plants retained. Seeds of individual plants were assessed for size and colour and the predominant seed type was bulked and multiplied to produce Farah which is now a well established cultivar in Australia. Critical steps in this breeding process were the identification of variation in the original population, self-pollination of selected plants, and retaining sufficient plants to ensure the background traits of Fiesta were maintained. This breeding method is suitable for overcoming a single deficiency in a cultivar, but is conservative with respect to increasing yield potential or improving other traits.

Resistance to chocolate spot is quantitative, and at best is partial in nature. Germplasm resistant to chocolate spot are mostly from the Andean region of Ecuador and Colombia [37,38] with relatively few other accessions with a good level of resistance, for example from the Maghreb [39]. The most chocolate spot resistant lines from the Andean region are characteristically very late flowering and maturing when sown in autumn in a Mediterranean-type environment, such as in southern Australia. While there does not appear to be any genetic or physiological linkage between resistance to chocolate spot and time of flowering, the nature of the genetic control for the two traits results in a very low proportion of a segregating population that is early flowering and resistant to chocolate spot [40].

A range of methods is used in screening faba beans for disease and pest resistance, including controlled environments, inoculated field nurseries, detached leaf methods and opportunistic observations of yield trials that are subjected to naturally occurring epidemics. For all methods, it is important to use appropriate isolates of the inoculum and to include control or reference varieties. Races of the major diseases have been described, with genotype $\times$ isolate interactions reported for ascochyta blight [35,41,42], chocolate spot [43] and rust [44]. In some of these studies the observations could also be explained by variation in aggressiveness in the isolates combined with heterogeneity in the faba bean genotypes. Nevertheless, the possibility of races, and in particular for ascochyta blight and rust, requires that a diverse set of isolates be used as inoculum in screening for resistance in a breeding program. In addition, a range of sources of disease resistance should be used when available. Multi-environment evaluation of resistant selections should be undertaken to establish whether the resistance is stable across environments. The Australian faba bean breeding program has 
collaborated with ICARDA with reciprocal exchange of material and results are generally in agreement between the two locations, particularly for ascochyta blight.

Field validation of disease resistant selections identified in controlled environments should be undertaken, and multi-environment testing will demonstrate whether the resistance is broad based or specific [35,45]. Highly heritable disease resistance, such as ascochyta blight, rust and cercospora leaf spot, can be selected on single plants and screening for these diseases can be undertaken in the $\mathrm{F}_{2}$ or $\mathrm{F}_{3}$ generations. Resistance that is partial, or of low to moderate heritability, for example, chocolate spot, bean leaf roll virus, bean yellow mosaic virus and broomrape cannot be selected effectively on single plants and replicated plots are required to identify highly resistant lines. Surplus seed of each line can be retained at seeding and used for subsequent development of resistant lines, thus avoiding the negative impact of cross-pollination between resistant and susceptible lines.

The parasitic weed crenate broomrape (Orobanche crenata Forsk.) is a root parasite with devastating effects on many crop legumes [46]. It is a significant constraint to production of faba bean throughout the Mediterranean Basin, and the spread of broomrape has resulted in a reduction in the area of faba bean and other pulse crops. The parasite obtains nutrients and water through haustoria connected with the host vascular system, leading to up to $80 \%$ of yield losses in faba bean fields with high levels of infestation through the Mediterranean basin, North Africa and the Middle East [46-48]. However, crenate broomrape does not occur in Australia. Although different control methods have been proposed [49-51], management of Orobanche remains a challenge since none of the measures have shown fully satisfactory and economically feasible results [48,52]. Resistance or tolerance to broomrape is a major objective of breeding programs in these regions. Though breeding for broomrape resistance remains the most promising strategy, traditional plant breeding has failed to produce stable resistance across time, location or parasite population [53].

Sources of resistance to broomrape are scarce and of complex nature. However, several resistant cultivars were released to farmers in Egypt under the commercial names 'Giza'. An acceptable level of resistance was found in Vf1071, an inbred line selected from cv. Giza 402 in Southern Spain [53,54]. This line has been used in breeding programs to develop the well-adapted, high yielding cv. Baraca [55].

\subsection{Breeding for Tolerance to Abiotic Stresses}

\subsubsection{Drought Tolerance}

Faba bean is grown mostly in cool season climates but also in sub-tropical regions over winter or spring [56]. It usually produces relatively high biomass as compared to other pulses and is typically more prone to moisture stress, particularly from the onset of flowering in shorter growing seasons [57]. Dryland production of faba bean is thus less reliable in climates that experience significant transient moisture stress or drought during vegetative growth. Under these conditions, the crop is short and produces only a few reproductive nodes [58].

Faba bean is highly responsive to irrigation [59] and relatively tolerant to water logging [60] compared to other pulse species. In Australia, this allows faba bean to be sown earlier in higher rainfall temperate climates to extend the length of the growing season and in wetter areas with duplex soils that are prone to water logging. 
In Mediterranean and sub-tropical climates which have a short growing season, early sowing is essential to minimise yield losses from moisture- and high temperature-stress [61] during reproductive development. Early maturing cultivars are now available that can better avoid such stresses. In Mediterranean and temperate climates the crop is highly reliant on the in-season rainfall, whereas in sub-tropical farming systems sub-soil moisture can often supply sufficient water until at least the onset of flowering stage and early podding [62].

Genetic improvement has focused on directly screening for yield responsiveness and yield potential in water limiting environments. Physiological traits such as earliness to flower, higher harvest index and better disease resistance can improve tolerance to moisture stress during the reproductive period [63]. As the crop is very leafy, variation for better leaf turgor [64] may contribute to higher drought tolerance per se but needs to be better understood. There also may be potential to produce growth types that are more determinate in flowering (i.e., ti types) to reduce competition between reproductive tissue and the growing vegetative apex for assimilates [65].

\subsubsection{Soil Limiting Factors}

In many dryland cropping regions, the utilisation of sub-soil water for plant growth and grain yield is compromised by increasing sodicity and soil salinity. Useful variation for tolerance to salinity appears to be present in faba bean $[66,67]$ that could improve water use efficiency in the soil compared to other pulses. Faba bean does not appear to be as sensitive to high soil boron (commonly found in alkaline sub-soils) in terms of plant injury or biomass reduction [68] and hence, improved tolerance is not an objective of breeding programs.

Faba bean is grown widely across both low and high $\mathrm{pH}$ soil types and associated micro-nutrient deficiencies (e.g., Zn, Fe, Mo, Mg) can sometimes occur. Although genetic variation may exist for tolerance to such deficiencies, breeding is limited to evaluation in target environments as sufficient micro-nutrients are typically applied in fertiliser at sowing or later with foliar applications if symptoms appear.

\subsubsection{High Temperature and Cold Injury}

As a cool season legume, high temperatures at flowering are likely to reduce pollen viability in faba bean, and interact with moisture stress to cause flower, ovule and pod abortion [69]. Potentially useful variation may be present at different reproductive growth stages following exposure to high temperature [70].

Faba bean pod walls are thick enough to protect developing ovules from cold injury which has allowed breeders to breed for earliness for autumn sown varieties. Vegetatively the crop can suffer physical cold injury and this is considered to be one of the main abiotic constraints for growing autumn-sown faba beans in cool temperate climates [71]. Screening in the field is difficult, but achievable with a reliable cold environment [72]. However, controlled environment screening may also be useful [71]. 


\subsection{Breeding for Quality Traits}

\subsubsection{Human Consumption}

Faba bean is widely grown for both human consumption and stock feed. Export of dry grain is dominated by Australia, France and the UK. The import market of dry grain for human consumption is relatively small (the sum of world imports is less than 300,000 tonnes/year) compared to other pulses such as chickpea, lentil and field pea.

Dry faba bean grain is used for human consumption in diverse cuisines either as a whole or processed product such as medamis (stewed beans), falafel (deep fried bean/vegetable mix), bussara (bean paste) and nabet soup (boiled germinated grain). By far the main importer of dry grain for human consumption is the Middle East-Mediterranean region, particularly Egypt. However, faba bean is an important food in China, which is the largest consumer of the crop but mostly as a vegetable (i.e., green seed and pods), and across the Latin based cultures of the south Americas.

Grain is processed to produce canned, crushed, dehulled, split or flour products all of which have different grain quality requirements and end-uses. Flour can be used as a source of vegetable protein in meat extenders and starch is extracted to make vermicelli, noodles, dumplings and steamed bread in Asia. Whole dry grain is also sprouted in some Asian countries for consumption as a vegetable or used as whole grain in cooking.

For canning uniform grain size and high hydration capacity are needed to produce a high quality product. The preferred grain size is driven by regional preference. For example, the Egyptian market prefers the larger size of Australian product compared to that from the UK or France. However, Saudi Arabia prefers small sized grain. Though broad bean is a large sized dry grain imported by Mediterranean countries (e.g., Italy, Spain) at a premium price, the market size is relatively very small.

Seed coat colour can be important as grain is traded initially on visual appearance, even though it is of little significance for end use quality per se. A lighter colour (i.e., light buff) is generally preferred and discoloration caused by age of the grain (i.e., darkening) or weather or disease damage is poorly perceived and can lead to discounted prices or market rejection. Low light and temperature storage conditions for dry grain can delay the darkening discoloration [73]. However, useful genetic variation has also been identified in breeding. Variation for the unique bean flavour and interaction with growing environment is sometimes referred to by trade for regional markets. However, the merit of targeting this in breeding is questionable. Tannin free types are accepted for dry grain human consumption markets but are likely to taste (e.g., less astringent) and cook differently (i.e., hydrate quicker) to traditional types consumed and imported historically.

\subsubsection{Animal Nutrition}

The animal feed markets use faba bean as a source of protein and energy [74]. Feeding studies show that faba bean is a good poultry feed with addition of supplemental methionine. The grain is also regularly used in feeding rations for pigs, dairy, beef cattle and sheep. Commercial faba bean grain has a protein content of around 24 to $30 \%$, and there is scope for genetic improvement [75]. Variation for sulphur content of methionine and cysteine is low and there is a negative genetic correlation with seed protein content [76] limiting the effectiveness of classical breeding. 
In Europe, the absence of polyphenolic substances (commonly known as tannins), as well as vicine and convicine, are breeding priorities because they decrease digestibility and biological value of the protein in animal feeding [77,78]. Dehulling is used to eliminate tannin mostly present in the seed coat and is of less importance than vicine and convicine which are thermostable and difficult to breakdown in processing. These glucosides can also trigger haemolytic anaemia or favism in humans that inherit Glucose-6-phosphate dehydrogenase (G6PD) deficiency. However, G6PD deficiency helps to protect against malaria [79].

Screening for zero-tannin genotypes is relatively easy as the absence of tannin in the seed coat is coded by two recessive genes, which act to block the synthesis of anthocyanin or anthocyanin's precursors, and plants that are homozygous recessive at either locus, produce white-flowers and zero-tannin seed. Zero-tannin cultivars are now available in Europe (e.g., 'Gloria'). However, the lack of plant anthocyanin may increase disease sensitivity of the crop at establishment and fungicidal seed dressing is needed [19].

Low vicine cultivars have been developed (e.g., 'Mélodie'). The trait is monogenetic recessive and a morphological marker (white hilum) is known.

Breeding for animal nutrition is focused in Europe where subsidies aim to increase faba bean production and decrease imports of vegetable protein, particularly soybean, whereas higher value human consumption markets and reliable production are a greater priority in Australia.

\section{Molecular Breeding: Progress and Prospects}

Molecular breeding strategies that integrate the latest innovations in genetics and genomics with traditional breeding strategies have many potential applications for future faba bean cultivar development [80], including:

(i) Improving the efficiency of selection: DNA-based markers and other genomic tools can be used to select for genes of importance more effectively and assess the existing genetic variation within the species to assist selecting parents for hybridization [81];

(ii) Enhancing favourable gene action: Molecular tools can be used to understand the gene action and breeding value at various loci distributed across the genomes. Molecular cloning of QTLs can provide novel insights about the biology and nature of quantitative traits, and

(iii) Expansion of useful genetic diversity for crop improvement: Molecular and recombinant DNA technology approaches can be used to identify and incorporate genes that are not otherwise accessible or available through crossing [82].

\subsection{Marker Assisted Selection}

Marker assisted selection (MAS) in breeding allows for a specific trait to be selected without the need of expressing and evaluating the associated phenotype. MAS is particularly valuable for traits requiring expensive, time-consuming or often unreliable screening methods (e.g., the selection of genes in complex host-pathogen interactions) and selection can be made in the absence of the disease or stress and in early stages of plant development. 
Early genetic studies used morphological and isozyme variation, but the availability of DNA based markers has facilitated the construction of linkage maps of faba bean. Linkage maps are useful for identifying chromosomal regions that contain genes controlling simple inherited traits and quantitative traits using QTL analysis [83]. They can then be used to reveal relationships or linkages between genes that may be relevant to breeders.

Isozymes, RAPDs and RFLPs were used to develop the first meaningful genetic linkage maps for faba bean in $F_{2}$ populations [84]. Later, SSRs specific for chromosome I were obtained and used for mapping purposes [85]. More recently, intron-targeted amplified polymorphic (ITAP) markers mapped in Medicago truncatula, soybean and lupin were used to develop the first gene-based genetic map of faba bean [5], which constitutes a reference for the future use of genomic and genetic information in faba bean genetic analysis and breeding. Several specific reviews with respect to genetic mapping, QTL analysis, genomics and molecular breeding are available $[4,9,86]$.

In faba bean, molecular markers have been sought both for simple and complex traits. In the case of major gene traits of interest, phenotyping methods have been developed that are relatively simple, allowing the accurate mapping of the gene. Traits such as rust resistance or seed quality parameters (absence of tannins or low content in vicine-convicine), are controlled by single genes and simple bulked segregant analysis has been used for the identification of markers that are tightly linked to the responsible genes [12-14,87].

For more complex traits, rapid and reliable screening methods, together with the saturation of the genomic regions associated with target regions and QTL validation in multiple environments and genetic backgrounds, are prerequisites to uncover reliable marker-trait associations. Mapping complex traits in faba bean, such as resistance to parasitic plants or pathogenic fungi has been attempted, opening new perspectives for successful MAS schemes in this crop. Results achieved so far for biotic and abiotic stresses, the principal antinutritional characters and morphological traits are summarized in Table 1. More important traits for breeding are described in detail.

\subsubsection{Markers for Ascochyta Resistance}

Progenies from two faba bean crosses (Vf6 $\times$ Vf136 and $29 \mathrm{H} \times \mathrm{Vf136}$ ) have been used to identify QTLs affecting ascochyta blight resistance. Vf136 is susceptible, Vf6 partially resistant and $29 \mathrm{H}$ resistant to ascochyta blight. Analysis of cross Vf6 $\times$ Vf136 against one isolate of $A$. fabae indicated a polygenic control determined by at least two QTLs ( $A f 1$ and $A f 2$ ), assigned to chromosomes III and II that explained 21 and $25 \%$ of the variability, respectively [88]. In a parallel study, in cross $29 \mathrm{H} \times \mathrm{Vf} 136$, 6 QTLs named $A f 3$ to $A f 8$ were detected for resistance against two different isolates of $A$. fabae in stems and leaves. However, only $A f 3$ and Af4 were effective against both isolates on both stems and leaves [89]. Interestingly, $A f 1$ [90] and $A f 3$ [89] were both assigned to chromosome III and might correspond to the same genomic regions. 
Table 1. Update of the molecular markers associated to gene(s)/QTLs of agronomic interest reported so far in faba bean (Main source: [9]).

\begin{tabular}{|c|c|c|c|c|c|}
\hline Trait & Loci/QTL & Chromosome & Mapping populations & Linked markers & References \\
\hline Rust resistance & Uvf1 & unknown & $2 \mathrm{~N} 52 \times \mathrm{Vf1} 16\left(\mathrm{~F}_{2}\right)$ & OPI20 ${ }_{900} /$ OPL $18_{1032}$ & {$[87]$} \\
\hline \multirow[t]{18}{*}{ Broomrape resistance } & Oc1 & I & $\mathrm{Vf6} \times \mathrm{Vf1} 136\left(\mathrm{~F}_{2}\right)$ & OPJ13 ${ }_{686} / \mathrm{OPAC} 02_{730}$ & [3] \\
\hline & Oc2 & VI & & $\mathrm{OPAC} 6_{342} / \mathrm{OPN} 07_{849}$ & \\
\hline & Oc3 & II & & OPW15 $5_{533} / \mathrm{OPAA} 07_{807}$ & \\
\hline & Oc2 & VI.B & Vf6 × Vf136 (RILs) & $\mathrm{OPAI}_{1018} / \mathrm{OPAC} 06_{396}$ & {$[91]$} \\
\hline & Oc3 & II.A & & OPM15 $794 /$ PisGEN 4_3_1 & \\
\hline & Oc4 & I.A & & $\mathrm{OPAB} 01_{438} / \mathrm{OPM} 18_{1192}$ & \\
\hline & Oc5 & I.A & & OPM1 $8_{620} / \mathrm{OPA} 17_{524}$ & \\
\hline & $\mathrm{Oc} 2{ }_{2} 3^{\mathrm{a}}$ & VI.B & Vf6 $\times$ Vf136 (RILs) & OPAG11/OPI5 & [92] \\
\hline & $\mathrm{Oc} 2 \_\mathrm{C} 4$ & VI.B & & OPAG11/OPI5 & \\
\hline & Oc2_M4 & VI.B & & $\mathrm{OPAI}_{13} 3_{1018} / \mathrm{OPAC} 6_{396}$ & \\
\hline & $\mathrm{Oc} 3 \_\mathrm{C} 3$ & II.A & & OPM15 $794 /$ Pis_GEN_4_3_1 & \\
\hline & Oc3_C4 & II.A & & OPM15 $794 /$ Pis_GEN_4_3_1 & \\
\hline & Oc4_C4 & I.A & & $\mathrm{OPB}^{0} 3_{289}$ & \\
\hline & Oc5_M4 & I.A & & $\mathrm{OPM} 18_{1620} / \mathrm{OPA} 17_{524}$ & \\
\hline & Oc6_C3 & I.A & & 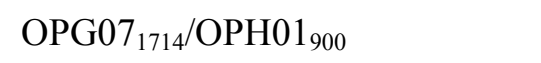 & \\
\hline & Oc7_C3 & II.A & & OPP 10 & \\
\hline & Oc8_M4 & II.A & & Pis_GEN_58_3_4_1/OPAF20 0 776 & \\
\hline & $\mathrm{Oc9} 9 \mathrm{C} 4$ & $\mathrm{~V}$ & & OPAD02 ${ }_{1282} \mathrm{OPK} 18_{1049}$ & \\
\hline
\end{tabular}


Table 1. Cont.

\begin{tabular}{|c|c|c|c|c|c|}
\hline Trait & Loci/QTL & Chromosome & Mapping populations & Linked markers & References \\
\hline \multirow{14}{*}{$\begin{array}{l}\text { Ascochyta blight } \\
\text { resistance }\end{array}$} & & III & & & \\
\hline & Af1 & & $\operatorname{Vf6} \times \operatorname{Vf1} 136\left(\mathrm{~F}_{2}\right)$ & OPA $11_{1045} / \mathrm{OPAB} 07_{1026}$ & [90] \\
\hline & Af2 & II & & OPE1 $7_{1272} / \mathrm{OPJ} 18_{626}$ & \\
\hline & Af3 & III & $29 \mathrm{H} \times \mathrm{Vf1} 136\left(\mathrm{~F}_{2}\right)$ & OPD16 $_{1732} / \mathrm{OPG} 4_{1131}$ & [89] \\
\hline & Af4 & unknown & & OPJ18 ${ }_{655} /$ OPG11 1118 & \\
\hline & Afl (DSL) ${ }^{b}$ & III.A & Vf6 × Vf136 (RILs) & OPAC06 $6_{1023}$ & [93] \\
\hline & Af1 (DSS) ${ }^{c}$ & III.A & & OPF08 & \\
\hline & Af2 (DSL) & II.A & & 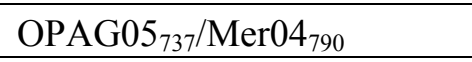 & \\
\hline & Af2 (DSS) & II.A & & OPD12 ${ }_{425} / \mathrm{OPE} 17_{1326}$ & \\
\hline & Afl (DSL) & III.A & Vf6 × Vf136 (RILs) & OPZ82 & [92] \\
\hline & Af1 (DSS) & III.A & & OPZ82 & \\
\hline & Af2 (DSL) & II.A & & 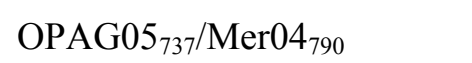 & \\
\hline & Af2 (DSS) & II.A & & OPD $12_{425} / \mathrm{OPE} 17_{1326}$ & \\
\hline & U_AUSPC-1 & & Côte d'Or $1 \times$ BPL 4628 & $\mathrm{U} 09_{1499} / \mathrm{B} 20_{803}$ & [71] \\
\hline \multirow{4}{*}{ Frost tolerance } & U AUSPC-2 & unknown & & $\mathrm{F} 15_{476} / \mathrm{I} 10_{661}$ & \\
\hline & U_AUSPC-3 & unknown & & $\mathrm{O} 18_{715} / \mathrm{O} 18_{737}$ & \\
\hline & H_AUSPC-1 & unknown & & $\mathrm{B} 13_{560}$ & \\
\hline & H_AUSPC-2 & unknown & & $\mathrm{I} 10_{661} / \mathrm{I}_{06} 6_{425}$ & \\
\hline \multirow[t]{2}{*}{ habit } & Vf_TFL1 & $\mathrm{V}$ & & CAPS-TFL1 (Hin1II) * & [10] \\
\hline & & & & Ti-dCAPS * & [11] \\
\hline \multirow[t]{2}{*}{ Zero tannins } & $\mathrm{zt}-1$ & unknown & Vf6 $\times \mathrm{zt}-1\left(\mathrm{~F}_{2}\right)$ & $\mathrm{SCC}_{551} / \mathrm{SCG} 11_{1171}$ & [13] \\
\hline & $\mathrm{zt}-2$ & unknown & Vf6 $\times \mathrm{zt}-2\left(\mathrm{~F}_{2}\right)$ & $\mathrm{SCAD} 6-\mathrm{B}_{565} / \mathrm{SCAD} 16-\mathrm{H}_{385}$ & [14] \\
\hline Low vicine-convicine & $v c-$ & unknown & Vf6 $\times v c-\left(\mathrm{F}_{2}\right)$ & $\mathrm{SCH} 1_{620} / \mathrm{SCAB} 12_{850}$ & [12] \\
\hline
\end{tabular}

* Diagnostic markers designed on the gene controlling the trait; ${ }^{\mathrm{a}}$ C3, C4 and M4 stand for Córdoba 2003, Córdoba 2004 and Megibar 2004, respectively; ${ }^{\mathrm{b}}$ DSL: disease severity in leaves; ${ }^{\mathrm{c}}$ DSS: disease severity in stems. 
QTL mapping studies should be independently confirmed in different genetic backgrounds and environments to demonstrate that DNA markers identified in one population are useful in different pedigrees [83]. To date, only a small fraction of the QTLs identified for important plant traits have been independently tested for confirmation. The validation may involve replication studies in independent populations (in particular, recombinant inbred lines, RILs), constructed from the same parental genotypes or with closely related genotypes used in the primary QTL mapping study [94]. In faba bean, this approach was recently carried out by studying 165 RILs developed by single-seed descent from the cross Vf6 $\times$ Vf136 [91]. The new molecular map allowed detecting Af1 and Af2 on the same chromosomes, explaining a similar percentage of the phenotypic variation. Fifteen common markers facilitated the comparison of homologous regions between maps and confirmed the occurrence of QTLs for ascochyta blight resistance in independent populations $\left(\mathrm{F}_{2}\right.$ and $\left.\mathrm{F}_{6}\right)$ for the first time.

The prospects of MAS for ascochyta resistance in faba bean breeding programs will depend on the extent to which QTL results can be extrapolated from one population to another. This fact is being pursued by developing a new map in the RIL population from the cross $29 \mathrm{H} \times \mathrm{Vf136}$. A number of common standard markers (SSRs and gene based markers) are being genotyped, in order to confirm the QTLs across generations ( $\mathrm{F}_{2}$ and RIL) and further to validate additional QTLs across different genetic backgrounds. Moreover, regions bearing stable QTLs are being saturated in both maps as a first step towards the development of reliable molecular markers useful for disease resistance selection.

\subsubsection{Markers for Rust Resistance}

Rust resistance is race-specific and monogenic, implying that the use of single resistance genes in cultivars would likely result in non-durable resistance [32,95]. Gene pyramiding of different sources into a single cultivar is known to increase the durability of this type of resistance [96]. MAS of markers tightly linked to different resistant genes would greatly facilitate this process. Bulked segregant analysis has been used to detect RAPD markers tightly linked to the gene causing hypersensitive resistance to rust (race 1) in the inbred line 2N52 [87]. Three RAPD markers $\left(\mathrm{OPD} 13_{736}, \mathrm{OPL}_{18} 8_{1032}\right.$ and OPI20 $\left.{ }_{900}\right)$ in coupling phase with the gene $(U v f-1)$ were mapped in $55 \mathrm{~F}_{2}$ plants. No recombinants between OPI $20_{900}$ and $U v f-1$ were detected. Two additional markers (OPP02 1172 and OPR07930) were linked to the gene in repulsion phase at a distance of 9.9 and $11.5 \mathrm{~cm}$, respectively [87]. However, these markers have not been adopted in any breeding programs.

\subsubsection{Markers for Broomrape Resistance}

The first study to identify QTLs controlling broomrape resistance in faba bean was conducted using an $\mathrm{F}_{2}$-derived population of a cross between the resistant line Vf136 and the susceptible line Vf6 [97]. Vf136 derives from a cross between the Spanish cultivar "Alameda" and Vf1071, a resistant line selected from Giza 402 and one of the main sources of broomrape resistance $[98,99]$. Three QTLs (named $O c$ ) were identified, suggesting that broomrape resistance in faba bean is a polygenic trait with major effects from a few single genes. $O c 1, O c 2$ and $O c 3$ were assigned to chromosome I, chromosome VI and linkage group 11, respectively, and collectively explain $74 \%$ of the total phenotypic variance $(37.3 \%, 11.3 \%$ and $25.5 \%$, respectively). All the resistance-enhancing alleles 
originated from the resistant parent Vf136. Oc1 and Oc3 had considerable dominant effects, whereas Oc2 displayed purely additive gene action [3].

In order to validate the QTLs identified in the $\mathrm{F}_{2}$ population, 165 RILs ( $\mathrm{F}_{6}$ generation) from the cross Vf6 $\times$ Vf136 were used to construct a new linkage map with a wide genome coverage [91]. To confirm the position and effects of the three QTLs identified in $\mathrm{F}_{2}$, validation experiments were carried out using the $\mathrm{F}_{6}$ progeny in three environments. Oc1, the major QTL identified in $\mathrm{F}_{2}$ and explaining the highest percentage of the phenotypic variance, was not further detected in the RILs in any of the environments [91]. This is probably due to overdominance displayed by the QTL in the $\mathrm{F}_{2}$. Dominance effects are known to be important in this generation but are absent in RILs. Moreover, some QTLs detected in early generations of maximum linkage disequilibrium are indeed due to multiple linked genes that may be separated via recombination [100], which could also explain this outcome. Indeed, two additional QTLs (Oc4 and Oc5) with small effects (17\% and 9\%) were detected in the same linkage group as $O c 1$, which is ascribed to chromosome I. Both QTLs were only expressed in one of the environments. Variations in the level of infestation and/or weather conditions could have contributed to differences in gene expression between environments.

In contrast to $O c 1$, both $O c 2$ and $O c 3$ showed consistency between $\mathrm{F}_{2}$ and $\mathrm{F}_{6}$ generations [3] since they were detected in at least two of the three environments confirming their environmental stability and pointing to their suitability as future targets for MAS [91].

The information available so far, especially that for resistance to Ascochyta and crenate broomrape, reveals the potential use of molecular markers for indirect selection for resistance in faba bean. Depending on their relative effects and position, some of the QTLs could be used in MAS approaches, after saturation of target regions to refine QTL position and identify the marker most closely linked to the resistance genes. Recent unpublished advances are integrated in Table 1.

\subsubsection{Markers for Anti-Nutritional Characters}

Vicine-convicine content may decrease up to 20 times due to the presence of the $v c$-allele that is linked to colourless hilum in the seeds [101]. RAPD markers linked to the recessive allele (vc-) were identified by analysing an $\mathrm{F}_{2}$ population derived from a cross between Vf6 and the $v c$-genotype [102]. Two RAPDs linked in coupling and repulsion phase to the $v c$-allele were identified and converted into SCARs (Sequence Characterized Amplified Regions). The loss of the initial polymorphism between pools was resolved by restriction analysis with HhaI for SCAR SCH01 620 and RsaI for SCAR SCAB12 850 , polymorphic between the parental lines. The simultaneous use of these CAPS (Cleavage Amplification Polymorphic sequences) allowed the accurate fingerprinting of the $v c$-allele in faba bean lines and could facilitate the development of cultivars with low vicine-convicine content and improved nutritional value although the simple visual assessment of hilum colour would remain as most cost effective (Table 1).

Tannin: Two recessive genes, $z t-1$ and $z t-2$, control the absence of tannins in faba bean seeds, generating white flower plants $[103,104]$. Four RAPD loci $\left(O P C 5_{551}\right.$, OPG15 600, OPG1 11171 and OPAF20 $0_{776}$ ) were identified that are tightly linked to $z t-1$ [13]. Two SCARs were developed, SCC $5_{551}$ associated to white flowers and zero tannin content and SCG1 $1_{1171}$ linked to coloured flowers and high tannin content. The genotyping of both markers in 37 faba bean lines differing in flower colour and 
tannin content resulted in a 95\% selection efficiency of the $z t-1$ genotypes [13]. The same strategy was used to identify a cost-effective marker linked to $z t-2$ [14]. Five RAPD markers linked in coupling and repulsion phase to the gene were identified and further converted into SCARs, although the initial polymorphism was lost. Restriction of the SCAR SCAD16 ${ }_{589}$ with AluI (SCAD16-A), Bsp120 (SCAD16-B) and HinfI (SCAD16-H) revealed differences due to the amplification of different loci. The consensus sequence of these CAP (Cleavage Amplification Polymorphism) revealed three bands, from which two new forward SCAR primers were developed based on the specific sequences from zero tannin and high tannin genotypes. A multiplex PCR was further developed to improve the efficiency of the marker screening with the same advantages as a co-dominant marker.

The SCAR markers linked to $z t-1, z t-2$ and $v c$ - will facilitate gene pyramiding in the production of faba bean cultivars with improved nutritional value for human and animal consumption. However, simple phenotypic measure of hilum and seed coat colour, possibly used with mass selection using electronic colour sorters would be a far more rapid, cheaper and easier way to select for recombinants that contain all genes of interest.

\subsubsection{Markers for Determinate Growth Habit}

Compared with the bulked segregant analysis, the use of a candidate gene approach potentially allows the development of diagnostic or perfect markers that are completely linked to the selected trait. This approach is only possible when the target gene is well characterized in the species or in related species carrying orthologous genes. Commonly, the co-dominant nature of these markers facilitates the identification of both homozygous and heterozygous individuals. This strategy has been used to develop molecular markers linked to growth habit in faba bean.

A gene determining growth habit $(C E N)$ was first cloned in Antirrhinum, and later several orthologous CEN/TFL1-like genes were identified in Arabidopsis, tomato, tobacco, pea, citrus, apple and other fruit species. Based on this information, an orthologue of CEN/TFL1 responsible of the growth habit in faba bean was identified and a CAPS marker based on a SNP (single nucleotide polymorphism) was developed at position 469 of the intron 2-3 [10]. This marker failed to detect some determinate genotypes since the SNP was a silent mutation. Further investigation allowed the development of a dCAPS marker based on a SNP associated with an amino acid change (Leu-9 to Arg) in the determinate growth habit genotypes. This new diagnostic marker was able to discriminate the gene of interest in a broad range of cultivars historically grown in Europe [11]. Although interesting research, these findings are unlikely to substitute for visual assessment of growth habits in early generation breeding where many other genes and combinations of gene are appraised and selected.

So far, marker research has been towards academic research rather than application and has not delivered benefits to breeding either in efficiency or effectiveness of selection. Unless research is closely linked to breeding and target traits are those where markers offer a significant advantage over existing phenotyping methods, the markers will not be implemented in commercially focused faba bean breeding programs. 


\subsection{Use of Genomic Technologies}

Among the cool season food legumes, faba bean genome is the largest (13 Gbp; Table 2). The large genome size of faba bean complicates the development of saturated genetic linkage maps, identification or location of important genes as well as functional genomic studies. However, combining functional, comparative and structural genomics can uncover increasing numbers of candidate genes. These genes represent excellent targets for QTL studies and may allow the identification of markers closely linked to genes of interest.

Table 2. Summary of genome sizes and ploidy level of cool season food legumes.

\begin{tabular}{lcc}
\hline Species & Genome Size & Ploidy Level \\
\hline Cicer arietinum (chickpea) & $740 \mathrm{Mbp}$ & $2 n=16$ \\
Lens culinaris (lentil) & $4 \mathrm{Gbp}$ & $2 n=14$ \\
Pisum sativum (field pea) & $5 \mathrm{Gbp}$ & $2 n=14$ \\
Vicia faba (faba bean) & $13 \mathrm{Gbp}$ & $2 n=12$ \\
\hline
\end{tabular}

\subsubsection{Comparative Genomics}

Until recently, most legume crops were categorized as 'genomic orphans' due to the lack of enriched genetic and genomic resources [105]. Therefore, most of the genetic and genomic studies within legumes have been based on comparative genomics with Medicago truncatula. Nevertheless, significant efforts have been made recently to enrich genetic and genomic resources for lentil [106], field pea and faba bean [107]. A large number of DNA based markers have now been developed, which can be used to understand the genetics of faba bean as well as for comparative genomic studies.

Within Fabaceae family, M. truncatula and Lotus japonicus have been extensively studied at genetic and genomics level as: (i) they have small genome sizes (500 Mbp and $470 \mathrm{Mbp}$, respectively) and relatively short life cycles [108]; (ii) a large number of germplasm collections are available for them that might be useful to look for genetic polymorphisms and to study various important traits. As a result, (i) several genetic linkage maps are available for both species [109-111]; (ii) whole genome sequencing projects have been undertaken for these species, providing the opportunity to identify putative orthologous gene sequence resources in other crop legume species, especially those located within the Galegoid clade (Figure 1) of the Fabaceae sub-family Papilionoideae [104]; (iii) several transcriptomic and proteomic tools have been developed in both model legumes [112-114]. All of the genomic and genetic resources developed in these model legume species can be used across other legume species such as faba bean, lentil, field pea and chickpea for comparative analysis (Figure 1).

Comparative mapping and genome analysis can help to understand conservation and differences in gene content and order among different taxa. The development of the Legume Information System (LIS; [115]) integrates genetic and physical map data and enables macrosynteny analyses to be carried out between legume species. The initial evidence of existence of macrosynteny between legume species was provided by comparison of genetic linkage maps of lentil and chickpea to field pea that indicated the presence of eight and five large syntenic blocks, respectively [116]. Comparisons between pea and $M$. sativa also revealed a significant conservation of the gene order in these two 
species [117]. Comparisons between M. truncatula and L. japonicus indicated that both genomes share at least 10 syntenic blocks among themselves [118].

Figure 1. Taxonomic relationship between model and cool season food legumes (Arrows indicate the possibility of adaptation of information derived from model species $(\mathrm{Mt}, \mathrm{Lj}$ ) across cool season food legumes- translational genomics); Figure adopted from [110].

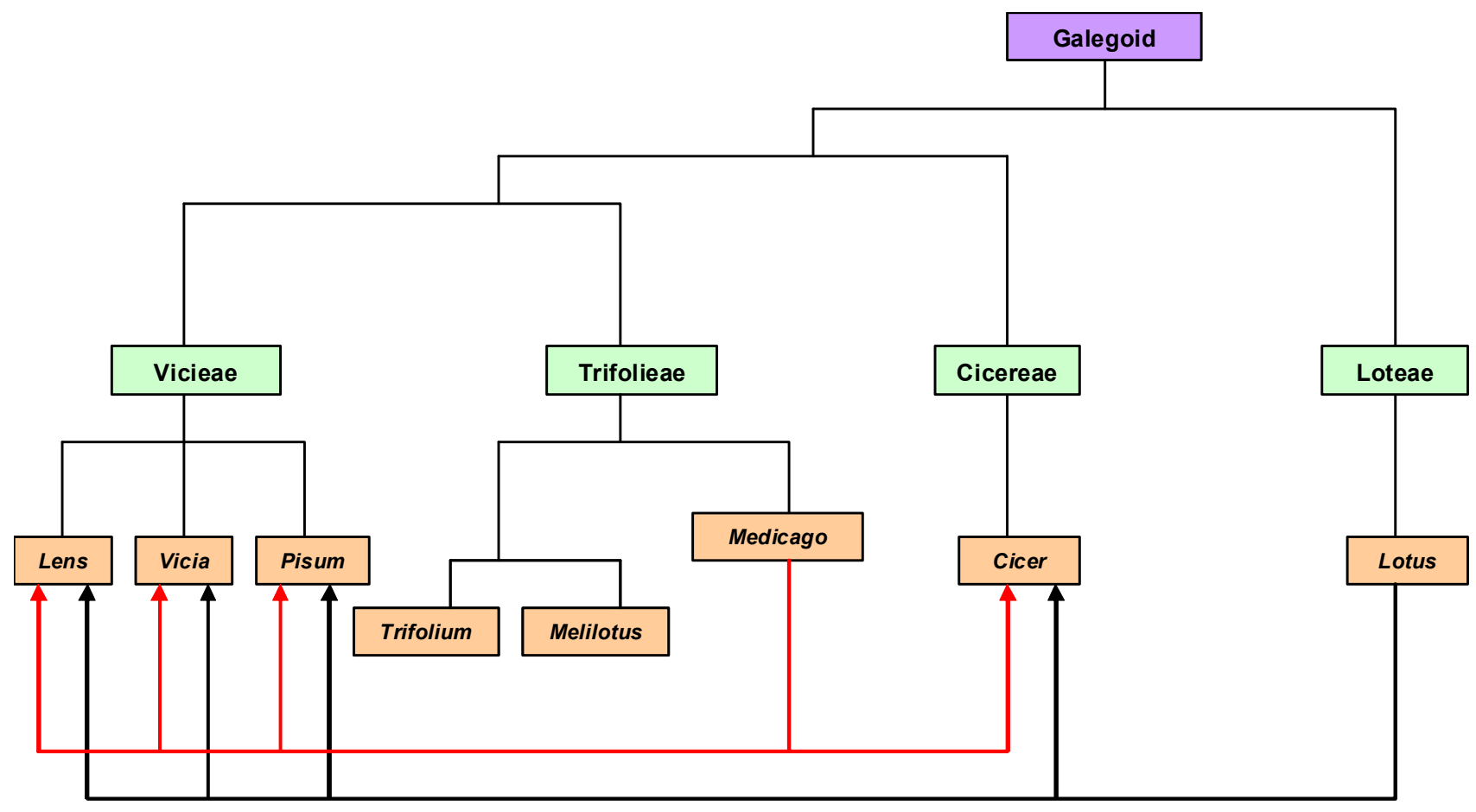

The genome of $M$. truncatula has been used as a reference for comparative mapping and to develop intron targeted gene based anchor markers for legume species [119]. These markers were used to study macrosyntenic relationships between lentil, chickpea, field pea, faba bean, lupins and common bean. Other comparative genomic studies also revealed that co-linearity exits between legume species to different extents depending on their phylogenetic distances. Though the genome size of faba bean is about 25-fold larger than the genome of $M$. truncatula, large-scale genome conservation is expected as both $M$. truncatula and $V$. faba belong to same clade. Hence, a comparative genetics approach between these two species would be useful. A composite genetic map of faba bean has been constructed [120] and intron-targeted gene-based markers have been developed and tested for faba bean. A total of 796 intron targeted amplified polymorphic markers were used to construct a comparative genetic map of faba bean and a simple and direct macrosyntenic relationship between faba bean and M. truncatula was observed [5]. This study also provided evidence for no polyploidisation, segmental duplication, or significant rearrangements in faba bean genome even though the genome size is massively large [5].

The high level of synteny that exists between most legume genomes should allow an efficient transfer of acquired knowledge in these model legumes to improve other poorly studied legume species such as faba bean. Recently, the whole genome of soybean (Glycine max) has been sequenced, which is proving to be very useful to provide further insights into legume genetics and biology [121]. Also, candidate genes identified by transcriptomic, proteomic or map-based cloning can be transferred to elite cultivars of faba bean after validation of its function through genetic transformation. Thus, 
comparative genomics has assisted in understanding the faba bean genome but has not delivered candidate genes from which novel genotypes or molecular markers can be developed and incorporated into breeding.

\subsubsection{Functional Genomics}

Functional genomics studies in faba bean are scarce, mostly academic and not directly related to crop improvement. Faba bean was used as a model plant to study stomatal movement [122-125]. An ABA-activated and $\mathrm{Ca}^{2+}$-independent protein kinase (AAPK) was identified involving in ABA action in guard cells [126]. A fia (faba bean impaired in ABA-induced stomatal closure) mutant in which the stomatal movement was disturbed was also identified in faba bean [127].

Full length cDNAs encoding three amino acid permeases were isolated from seed-specific libraries of faba bean [128]. The predicted proteins VfAAP1, VfAAP3 and VfAAP4 share up to 66\% identity among themselves. Functional characterization of VfAAP1 and VfAAP3 showed that these permeases transport a broad range of amino acids [128]. However, VfAAP1 had a preference for cysteine and VfAAP3 for lysine and arginine. Cysteine repressed the expression of the GUS reporter gene under control of the VfAAP1 promoter, indicating that this transporter is modulated at the transcriptional level [128].

Legumin amounts to approximately $55 \%$ of the seed protein in faba bean and it is a representative of the $12 \mathrm{~S}$ storage globulin family. The $12 \mathrm{~S}$ storage globulins are hexameric holoprotein molecules composed of different types of polymorphic subunits encoded by a multigene family [129]. In faba bean, isolation of at least a vicilin gene [130] and of four legumin genes have been reported [131]. The subunits of both legumin and vicilin were found to have a wide range of heterogeneity [131]. For example, legumin was found to be composed of 29 disulphide-linked subunit pairs with different molecular weight and/or isoelectric point, while vicilin composed of as many as 59 subunits with different isoelectric points [131].

Faba bean is an excellent candidate crop to study the genetic basis for nitrogen input into temperate agricultural systems [116,132]. A cDNA library derived from root nodules was used to investigate nodule-specific clones in faba bean [133,134]. VfSUCS was found to encode a sequenced sucrose synthase and served as a source of energy in symbiotic nitrogen fixation [135]. VfNOD32 encodes a nodulin with sequence similarities to chitinases [124]. Some faba bean nodulin genes encoded glycine-rich proteins [136]. The faba bean leghemoglobin gene VfLb29 was specifically active in the infected root nodules and in arbuscule-containing cells of mycorrhizal roots. Its promoter was used to test the infected activity in root nodule cells and in the arbuscule-containing cells of mycorrhizal roots from different legume and nonlegume plants [137-139]. The information outlined shows that functional genomics has as yet had no impact on faba bean breeding internationally.

\subsection{Genetic Transformation}

The development of genetic transformation techniques and transgenic faba bean are of commercial interest as they might facilitate the production of cultivars with improved characteristics, when useful resistance or tolerance genes to biotic and abiotic constraints may not be available in the primary gene pool of faba bean, and it would be difficult to transfer these genes through interspecific crossing [140-142]. 
Development of transgenic faba bean requires efficient and reproducible protocols for both regeneration and genetic transformation and suitable resistance or tolerance genes from other species.

\subsubsection{In vitro Regeneration}

The investigation of in vitro regeneration of faba bean has been extensive since 1960s. The first attempts to cultivate faba bean in vitro focused on the optimal growth of callus tissue or suspension cultures rather than the induction of shoot morphogenesis and plant regeneration [143-145]. The influence of media composition and explant source on the initiation and maintenance of cultures were tested and the conditions optimized for maximum increase in callus fresh weight. The morphogenic potential of faba bean cells cultured in vitro was low [146]. To develop a system for plant regeneration from single cells, callus and cell suspension cultures were established over a long period of time, but all attempts to initiate shoot regeneration remained unsuccessful. A serious constraint in faba bean tissue culture is the deterioration of explant material and cultivated tissue as a result of the action of phenolic compounds. The effect of various chemical and physical parameters in axillary shoot cultures was examined and low temperatures were found to limit the formation of phenolics [147,148]. Plantlet regeneration from explants lacking pre-existing shoot meristems was first claimed by [149].

After the protoplasts were isolated from leaves and shoots [150,151] and suspension cells [152], the regeneration of faba bean plant from protoplasts was reported [153]. Somatic embryogenesis in callus and suspension cultures derived from immature cotyledons of faba bean [154], a protocol in which plantlets derived from somatic embryos could be grown to maturity [155] and an improved protocol combined with the Agrobacterium tumefaciens-mediated gene transfer [156] were subsequently been achieved.

\subsubsection{Genetic Transformation}

Several investigators worked extensively on faba bean transformation and regeneration of transgenic plants [157-161]. The first attempts to transfer foreign genes into faba bean were attempted using Agrobacterium rhizogenes containing the binary vector pGSGluc1 carrying nptII and uidA genes under the control of the bidirectional TR1/2 promoter [160]. Beta-glucuronidase (GUS)-positive roots and subsequently transgenic calli lines were obtained. A similar study using an A. rhizogenes strain containing pBin19 for inoculation of faba bean cotyledons and stem tissue led to successful transfer of the nptII marker gene [161]. However, no transgenic faba bean plants were regenerated in any of these studies. The lack of an efficient protocol for the regeneration of transgenic plants was the main obstacle to faba bean transformation. Bacteria carrying shooty types Ti-plasmids, pGV2215 and pGV2235, were tried but neither of the two mutants appeared to improve regeneration [157]. Finally, the first transgenic faba bean plants were recovered from transformed tissues through de novo regeneration using thidiazuron (TDZ) [162]. The second successful protocol was based on direct shoot organogenesis from meristematic cells of mature or immature embryo axes [163].

The two successful studies demonstrated that transgenic approach could be used to improve protein quality in faba bean, and the bar gene (PPT acetyltransferase) could be effectively used as a selective agent of transgenic individuals, instead of the unpopular antibiotic resistance. Though the major hindrances in generating transgenic faba bean plants have been overcome, the number of transgenes 
that have been introduced into the faba bean genome is still limited. There are numerous traits that would be suitable for improving faba bean yield and nutritional quality. However, to complete the whole procedure of generating a commercial faba bean line, starting with the newly developed transgenic plant, then outcrossing the new trait into economically valuable genotypes, and eventually getting the approval for registration of the transgenic line, could take many years to achieve [164]. Furthermore, the acceptance of transgenic faba beans in the international marketplace, particularly Egypt, is unclear and therefore risky to pursue for large exporters such as Australia or the European Union.

\section{The Impact of Molecular Technologies on Faba Bean Breeding}

The impact of molecular technologies in the faba bean breeding program has been minimal and unlikely to be realized for many years as research is still in the 'technology innovation phase' and still evolving. However, these evolving molecular technologies offer opportunities to improve our genetic understanding of faba bean at the gene and genomic levels and offer the potential for the use of molecular tools in breeding as technologies improve and become cheaper to implement in research and breeding.

\subsection{New Approaches for More Efficient Targeted Marker Development}

Though faba bean maps are being continuously enriched by new SSRs, RGAs (resistance gene analogues) [165,166] and PCR gene-derived markers, new approaches are needed for efficient mapping of its large genome. The availability of genome sequences of model species, as well as the sequence information from expressed sequence tags (ESTs) has led to the development of a new generation of gene-targeted or functional markers. Within the comparative mapping program of the European GLIP project [167] a number of intron-targeted gene-based anchor markers were developed, using M. truncatula and pea as reference genomes.

Moreover, a number of ITAPs (intron-targeted amplified polymorphic markers) have been developed after alignment of M. truncatula, G. max and Lupinus spp. database EST sequences [5]. More than 150 orthologous codominant cross-species markers were deployed to produce the first exclusively gene-based genetic linkage map in this species, using an $\mathrm{F}_{6}$ population developed from Vf6 $\times$ Vf27 [5]. This map is being used at present to identify genes and QTLs related to yield and other agronomic related components. Moreover, genotyping of some of these ESTs in former faba bean maps mentioned in this review (Vf6 $\times \mathrm{Vf136}$ and Vf29H $\times \mathrm{Vf136}$ ) is being carried out with the aim of developing a composite genetic map in the near future.

Recent advances in next generation sequencing technologies enable the generation of large volumes of sequence efficiently and cost-effectively $[168,169]$. This has led to a revolution in biological and agricultural applications including identification of genes correlated with key breeding traits through high-density SNP marker and genome-wide association analysis studies (GWAS) [170,171]. Another outcome is the ability to accurately identify sequences flanking short sequence repeat (SSR) regions of faba been for use as locus-specific markers for downstream genotyping, which was done in ICS of CAAS and DNA sequences data of around 280,000 putative SSR loci were obtained. Using next 
generation sequencing for molecular marker development and construction of a saturated linkage map will be a major milestone for faba bean research.

\subsection{New Perspectives for Effective MAS}

Limited literature exists in legumes on gene transfer or gene pyramiding using MAS, and the few reports are mostly focussed on soybean, common bean and pea [172]. Recent work on tagging QTLs for important faba bean disease resistance traits, reveal new perspectives for effective MAS schemes in this species [3,89-91]. However, saturation of target regions associated with QTLs and validation in multiple environments and genetic backgrounds are necessary steps in the detection of reliable marker-trait associations.

If marker technologies can further reduce the cost of MAS considerably, the impact of MAS on faba bean breeding may be significantly enhanced and adopted in areas such as use of (i) marker for the selection of parents in breeding programmes; (ii) MAS for high-priority traits that are difficult, time consuming or expensive to measure; (iii) markers to minimize linkage drag via recombinant selection; (iv) screening for multiple traits at a single plant for gene pyramiding; (v) MAS to rapidly eliminate unsuitable lines after early generation selection, thus allowing breeders to concentrate on the most promising materials in breeding programmes [81], and thereby accelerating faba bean cultivar release.

\subsection{Identification and Characterisation of Candidate Genes}

The identification of candidate genes and the elucidation of their role are facilitated by combining QTL analysis with different sources of information and technological platforms. The progress of technologies involving high throughput profiling of the transcriptome, proteome and metabolome offers the possibility of investigating the concerted response of thousands of genes to key biotic and abiotic stresses. Some of these genomic tools have been used in faba bean crop improvement within the framework of the ERA-PG project LEGRESIST [173]. Super SAGE technology was employed to obtain the stress transcriptomes of different legume plants (faba bean, chickpea, pea, lentil and grass pea (Lathyrus sativus L.) infected by their corresponding Ascochyta pathogens [174]. Moreover, a faba bean cDNA library is available with transcriptomic data of faba bean interaction with this pathogen.

\section{Future Perspectives}

As the wild ancestor of faba bean has not been discovered or has become extinct, ex situ collections are crucial for the present and future breeding activities of this crop [18]. Also, due to the technical difficulties of achieving interspecific crosses or of producing transgenic lines with $V$. faba, breeders are currently confined to natural variability within the species or to mutagenesis, which is still underexploited in faba bean [18]. One potential area for mutation research that could be adopted quickly as a breeding objective is the identification of faba bean genotypes with tolerance to herbicides for in-crop control of broad leaf weeds. There are very few options for in-crop control of broad leaf weeds and the risk of severe weed infestation and build-up of the weed seed bank is a disincentive to adoption of faba bean in some regions of Australia. Tolerance to specific herbicides, for instance Glyphosate, would also assist in management of broomrape. Naturally occurring and induced variation 
in tolerance to herbicides has been identified for other grain legume crops such as lentil and similar variation could be exploited in faba bean.

A significant genomic resource was recently generated by sequencing of the faba bean transcriptome [107]. A total of 304,680 reads were generated from a range of sampled tissues from 2 faba bean genotypes (Icarus, Ascot) using the GS FLX Titanium chemistry, and a large number of SSRs and SNPs have been identified [107]. These markers may become very useful for understanding genetic diversity, cultivar identification, linkage mapping and QTL studies to understand traits of interest in faba bean. Once the QTLs have been identified, fine mapping approaches can be used to identify diagnostic markers. With the advancement in sequencing technology and the sequencing costs coming down, it will also be feasible to sequence the whole genome of faba bean. This will provide further insights into understanding the genes of interest, their functions and finally integrating this knowledge to improve breeding strategies.

Though there are many prospects for integrating molecular biology with traditional breeding, there are a few potential problems that need to be addressed. Once enabling technologies in biotechnology and genomics become available, economic factors often determine the degree to which these innovations are integrated into existing breeding programs. Although genetic studies have identified chromosomal regions and linked markers, traditional breeding programs continue to use phenotypic selection methods to identify genotypes that are resistant to current isolates of pathogen. The adoption of markers in routine screening for complex diseases in small crops will continue to be limited due to (i) the need for resistant varieties in the field, but a lack of understanding between molecular studies and "real world" needs and (ii) additional expenses, complexity and expertise needed for identifying, developing and implementing reliable molecular markers. The need to overcome these limitations is further demonstrated by marker research for broomrape resistance whereby molecular breeding programs have no consistent markers available even after 10 years of research. A major problem with markers for complex diseases is that they can only be applied to known genes and neglect the genes used in breeding programs that have not been characterised or the combination of genes that may provide resistance to complex pathogen populations in the field.

Therefore, the broad applicability of molecular tools in conventional faba bean breeding will remain a topic of debate [175]. The other potential factors that limit the application of molecular approaches into faba bean breeding include: (i) requirement of training and expertise in both molecular biology and faba bean breeding; (ii) the need for bigger investments for infrastructure for molecular genetics and genomics of faba bean. These problems can be easily overcome by national and international collaborations. Major efforts are needed to be made to implement education programs that can promote training in molecular faba bean breeding. Most importantly, research and breeding programs must be closely linked to ensure that the research is targeting and delivering the traits where molecular markers can be applied effectively in breeding.

\section{Acknowledgments}

Support for this work in Australia was provided by the Grains Research and Development Corporation. A.T. acknowledges the support for the work provided by the Spanish Ministerio de 
Ciencia e Innovación (MICINN) projects AGL-2008-02305 and RTA2010-00059, co-financed with FEDER.

\section{References and Notes}

1. Crépona, K.; Marget, P.; Peyronnet, C.; Carrouéea, B.; Arese, P.; Duc, G. Nutritional value of faba bean (Vicia faba L.) seeds for feed and food. Field Crop. Res. 2010, 115, 329-339.

2. FAOSTAT. 2010 Production-Crops. Available online: http://faostat.fao.org (accessed on 2 May 2012).

3. Roman, B.; Torres, A.M.; Rubiales, D.; Cubero, J.I.; Satovic, Z. Mapping of quantitative trait loci controlling broomrape (Orobanche crenata Forsk.) resistance in faba bean (Vicia faba L.). Genome 2002, 45, 1057-1063.

4. Torres, A.M.; Roman, B.; Avila, C.M.; Satovic, Z.; Rubiales, D.; Sillero, J.C.; Cubero, J.I.; Moreno, M.T. Faba bean breeding for resistance against biotic stresses: Towards application of marker technology. Euphytica 2006, 147, 67-80.

5. Ellwood, S.R.; Phan, H.T.; Jordan, M.; Hane, J.; Torres, A.M.; Avila, C.M.; Cruz-Izquierdo, S.; Oliver, R.P. Construction of a comparative genetic map in faba bean (Vicia faba L.); conservation of genome structure with Lens culinaris. BMC Genomics 2008, 9, 380.

6. van de Ven, W.T.G.; Waugh, R.; Duncan, N.; Ramsay, G.; Dow, N.; Powell, W. Development of a genetic linkage map in Vicia faba using molecular and biochemical techniques. Asp. Appl. Biol. 1991, 27, 49-54.

7. Ramsay, G.; van de Ven, W.; Waugh, R.; Griffiths, D.W.; Powell, W. Mapping quantitative trait loci in Faba beans. In Proceedings of the $2^{\text {nd }}$ European Conference on Grain Legumes, Copenhagen, Denmark; AEP (1'Association Européene de Recherche sur les Protéagineuse), Ed.; Copenhagen, Denmark, 1995; pp. 444-445.

8. Satovic, Z.; Torres, A.M.; Cubero, J.I. Genetic mapping of new morphological, isozyme and RAPD markers in Vicia faba L. using trisomics. Theor. Appl. Genet. 1996, 93, 1130-1138.

9. Torres, A.M.; Avila, C.M.; Gutierrez, N.; Palomino, C.; Moreno, M.T.; Cubero, J.I. Marker-assisted selection in faba bean (Vicia faba L.). Field Crop. Res. 2010, 115, 243-252.

10. Avila, C.M.; Nadal, S.; Moreno, M.T.; Torres, A.M. Development of a simple PCR-based marker for the determination of growth habit in Vicia faba L. using a candidate gene approach. Mol. Breed. 2006, 17, 185-190.

11. Avila, C.M.; Atienza, S.G.; Moreno, M.T.; Torres, A.M. Development of a new diagnostic marker for growth habit selection in faba bean (Vicia faba L.) breeding. Theor. Appl. Genet. 2007, 115, 1075-1082.

12. Gutierrez, N.; Avila, C.M.; Duc, G.; Marget, P.; Suso, M.J.; Moreno, M.T.; Torres, A.M. Markers to assist selection for low vicine and convicine contents in faba bean (Vicia faba L.). Theor. Appl. Genet. 2006, 114, 59-66.

13. Gutierrez, N.; Avila, C.; Rodriguez-Suarez, C.; Moreno, M.; Torres, A. Development of SCAR markers linked to a gene controlling absence of tannins in faba bean. Mol. Breed. 2007, 19, 305-314. 
14. Gutierrez, N.; Avila, C.M.; Moreno, M.T.; Torres, A.M. Development of SCAR markers linked to $z t-2$, one of the genes controlling absence of tannins in faba bean. Aust. J. Agric. Res. 2008, $59,62-68$.

15. Tanno, K.; Willcox, G. How fast was wild wheat domesticated? Science 2006, 311, 1886.

16. Cubero, J.I. On the evolution of Vicia faba L. Theor. Appl. Genet. 1974, 45, 47-51.

17. Paull, J.G.; Kimber, R.; van Leur, J. Faba bean breeding and production in Australia. Grain Legum. 2011, 56, 15-16.

18. Duc, G.; Bao, S.; Baum, M.; Redden, R.; Sadiki, M.; Suso, M.J.; Vishniakova, M.; Zong, X. Diversity maintenance and use of Vicia faba L. genetic resources. Field Crops Res. 2010, 115, 270-278.

19. Bond, D.A. Recent developments in breeding field beans (Vicia faba L.). Plant Breed. 1987, 99 , $1-26$.

20. Briggs, F.N.; Knowles, P.F. Introduction to Plant Breeding; Reinhold Publishing Corporation: New York, NY, USA, 1967; p. 426.

21. Link, W.; Schill, B.; Kittlitz, E.V. Breeding for wide adaptation in faba bean. Euphytica 1996, 92, 185-190.

22. Bond, D.A. Prospects for commercialisation of $F_{1}$ hybrid field beans Vicia faba L. Euphytica 1989, 41, 81-86.

23. Link, W.; Ederer, W.; Gumber, R.K.; Melchinger, A.E. Detection and characterization of two new CMS systems in faba bean (Vicia faba). Plant Breed. 1997, 116, 158-162.

24. Hanounik, S.B.; Robertson, L.D. Resistance in Vicia faba germplasm to blight caused by Ascochyta fabae. Plant Dis. 1989, 73, 202-205.

25. Kittlitz, E.V.; Ibrahim, K.I.M.; Ruckenbauer, P.; Robertson, L.D. Analysis and use of inter-pool crosses (Mediterranean $\times$ Central European) in faba beans (Vicia faba L.). Plant Breed. 1993, 110, 307-314.

26. Annicchiarico, P.; Iannucci, A. Breeding strategy for faba bean in Southern Europe based on cultivar responses across climatically contrasting environments. Crop Sci. 2008, 48, 983-991.

27. Bao, S. Yunnan Academy of Agricultural Sciences: Kunming, China. Personal communication, 2004.

28. Frauen, M.; Sass, O. Inheritance and performance of the stiff-strawed mutant in Vicia faba L. In Proceedings of XII EUCARPIA Congress, Göttingen, Germany, 1989; Volume 15, pp. 13-18.

29. Nadal, S.; Moreno, M.T.; Cubero, J.I. Registration of "Retaca" faba bean. Crop Sci. 2004, 44, 1865.

30. Adisarwanto, T.; Knight, R. Effect of sowing date and plant density on yield and yield components in the faba bean. Aust. J. Agric. Res. 1997, 48, 1161-1168.

31. Loss, S.P.; Siddique, K.H.M.; Jettner, R.; Martin, L.D. Responses of faba bean (Vicia faba L.) to sowing rate in south-western Australia. I. Seed yield and economic optimum plant density. Aust. J. Agric. Res. 1998, 49, 989-997.

32. Sillero, J.C.; Villegas-Fernández, A.M.; Thomas, J.; Rojas-Molina, M.M.; Emeran, A.A.; Fernández-Aparicio, M.; Rubiales, D. Faba bean breeding for disease resistance. Field Crops Res. 2010, 115, 297-307.

33. Kharbanda, P.D.; Bernier, C.C. Cultural and pathogenic variability among isolates of Ascochyta fabae. Can. J. Plant Pathol. 1980, 2, 139-142. 
34. Sillero, J.C.; Morenoa, M.T.; Rubialesb, D. Characterization of new sources of resistance to Uromyces viciae-fabae in a germplasm collection of Vicia faba. Plant Pathol. 2000, 49, 389-395.

35. Hanounik, S.B.; Robertson, L.D. Resistance in Vicia faba plasm to blight caused by Ascochyta fabae. Plant Disease 1989, 73, 202-205.

36. Kimber, R.B.E.; Davidson, J.A.; Paull, J.G. Using genetic diversity within faba bean germplasm to develop resistance to ascochyta blight. In Proceedings of the 1st International Ascochyta Workshop on Grain Legumes, Le Trodet, France, 2-6 July 2006.

37. Bond, D.A.; Jellis, G.J.; Rowland, G.G.; Le Guen, J.; Robertson, L.D.; Khalil, S.A.; Li-Juan, L. Present status and future strategy in breeding faba beans (Vicia faba L.) for resistance to biotic and abiotic stresses. Euphytica 1994, 73, 151-166.

38. Hanounik, S.B.; Robertson, L.D. New sources of resistance in Vicia faba to chocolate spot caused by Botrytis fabae. Plant Dis. 1988, 72, 696-698.

39. Bouhassan, A.; Sadiki, M.; Tivoli, B. Evaluation of a collection of faba bean (Vicia faba L.) genotypes originating from the Maghreb for resistance to chocolate spot (Botrytis fabae) by assessment in the field and laboratory. Euphytica 2004, 135, 55-62.

40. Paull, J.G. University of Adelaide: Adelaide, Australia. Personal observation, 2012.

41. Rashid, K.Y.; Bernier, C.C.; Conner, R.L. Evaluation of fava bean for resistance to Ascochyta fabae and development of host differentials for race identification. Plant Dis. 1991, 75, $852-855$.

42. Kohpina, S.; Knight, R.; Stoddard, F.L. Variability of Ascochyta fabae in South Australia. Aust. J. Agric. Res. 1999, 50, 1475-1481.

43. Hanounik, S.B.; Maliha, N. Horizontal and vertical resistance in Vicia faba to chocolate spot caused by Botrytis fabae. Plant Dis. 1986, 70, 770-773.

44. Rashid, K.Y.; Bernier, C.C. Evaluation of resistance in Vicia faba to two isolates of the rust fungus Uromyces viciae-fabae from Manitoba. Plant Dis. 1984, 68, 16-18.

45. Villegas-Fernández, A.M.; Sillero, J.C.; Emeran, A.A.; Flores, F.; Rubiales, D. Multiple-disease resistance in Vicia faba: multi-environment field testing for identification of combined resistance to rust and chocolate spot. Field Crops Res. 2011, 124, 59-65.

46. Rubiales, D.; Fernández-Aparicio, M. Innovations in parasitic weeds management in legume crops. A review. Agron. Sustain. Dev. 2012, 32, 433-449.

47. Gressel, J.; Hanafi, A.; Head, G.; Marasas, W.; Obilana, A.B.; Ochanda, J.; Souissi, T.; Tzotzos, G. Major heretofore intractable biotic constraints to African food security that may be amenable to novel biotechnological solutions. Crop Prot. 2004, 23, 661-689.

48. Pérez-de-Luque, A.; Eizenberg, H.; Grenz, J.H.; Sillero, J.C.; Ãvila, C.; Sauerborn, J.; Rubiales, D. Broomrape management in faba bean. Field Crops Res. 2010, 115, 319-328.

49. Joel, D.M. The long-term approach to parasitic weeds control: manipulation of specific developmental mechanisms of the parasite. Crop Protect. 2000, 19, 753-758.

50. Mauromicale, G.; Restuccia, G.; Marchese, M. Soil solarization, a nonchemical technique for controlling Orobanche crenata and improving yield of faba bean. Agronomie 2001, 21, 757-765. 
51. Rubiales, D. Parasitic plants, wild relatives and the nature of resistance. New Phytol. 2003, 160, 459-461.

52. Stoddard, F.L.; Nicholas, A.H.; Rubiales, D.; Thomas, J.; Villegas-Fernández, A.M. Integrated pest management in faba bean. Field Crops Res. 2010, 115, 308-318.

53. Cubero, J.I. Breeding for resistance to Orobanche species: A review. In Proceedings of the International Workshop on Orobanche Research, Obermarchtal, Germany, 19-22 August 1989; Wegmann, K., Musselman, L.J., Eds.; Eberhard-Karls-Universität: Tübingen, Germany, 1991; pp. 257-277.

54. Sillero, J.C.; Rubiales, D.; Cubero, J.I. Risks of Orobanche screenings based only on final number of emerged shoots per plant. In Advances in Parasitic Plant Research; Moreno, M.T., Cubero, J.I., Berner, D., Joel, D., Musselman, L.J., Parker, C., Eds.; Junta de Andalucì: Córdoba, Spain, 1996; pp. 652-657.

55. Cubero, J.I.; Moreno, M.T. Studies on resistance to Orobanche crenata in Vicia faba. in Resistance to Broomrape-The State of the Art; Cubero, J.I., Moreno, M.T., Rubiales, D., Sillero, J.C., Eds.; DGIFA: Junta de Andalucía, Sevilla, Spain, 1999; pp. 9-15.

56. Muehlbauer, F.J.; Kaiser, W.J.; Simon, C.J. Potential for wild species in cool season food legume breeding. Euphytica 1993, 73, 109-114.

57. Khan, H.R.; Paull, J.G.; Siddique, K.H.M.; Stoddard, F.L. Faba bean breeding for drought-affected environments: A physiological and agronomic perspective. Field Crops Res. 2010, 115, 279-286.

58. French, R.J. The risk of vegetative water deficit in early-sown faba bean (Vicia faba L.) and its implications for crop productivity in a Mediterranean-type environment. Crop Pasture Sci. 2010, $61,566-577$.

59. Oweis, T.; Hachum, A.; Pala, M. Faba bean productivity under rainfed and supplemental irrigation in northern Syria. Agr. Water Manag. 2005, 73, 57-72.

60. Solaiman, Z.; Colmer, T.D.; Loss, S.P.; Thomson, B.D.; Siddique, K.H.M. Growth responses of cool-season grain legumes to transient waterlogging. Aust. J. Agric. Res. 2007, 58, 406-412.

61. Loss, S.P.; Siddique, K.H.M.; Tennant, D. Adaptation of faba bean (Vicia faba L.) to dryland Mediterranean-type environments. III. Water use and water-use efficiency. Field Crop. Res. 1997, 54, 153-162.

62. Turpin, J.E.; Robertson, M.J.; Hillcoat, N.S.; Herridge, D.F. Faba bean (Vicia faba) in Australia's northern grains belt: Canopy development, biomass, and nitrogen accumulation and partitioning. Aust. J. Agric. Res. 2002, 53, 227-237.

63. Khan, H.R.; Paull, J.G.; Siddique, K.H.M.; Stoddard, F.L. Faba bean breeding for drought-affected environments: A physiological and agronomic perspective. Field Crops Res. 2009, 115, 279-286.

64. Khan, H.R.; Link, W.; Hocking, T.J.H.; Stoddard, F.L. Evaluation of physiological traits for improving drought tolerance in faba bean (Vicia faba L.). Plant Soil 2007, 292, 205-217.

65. Stelling, D. Heterosis and hybrid performance in topless faba beans (Vicia faba L.) Euphytica 1997, 97, 73-79. 
66. Boddi, M.; Enneking, D.; Materne, M.; Paull, J.; Noy, D. Genetic variability in faba beans (Vicia $\mathrm{faba}$ ) in response to $\mathrm{NaCl}$. Contemporary crop improvement-A tropical view. In Proceedings of the 14th Australasian Plant Breeding (APB) Conference and 11th Society for the Advancement of Breeding Researches in Asia and Oceania (SABRAO) Conference, Cairns, Australia, 10-14 August 2009.

67. Tavakkoli, E.; Paull, J.; Rengasamy, P.; McDonald, G.K. Comparing genotypic variation in faba bean (Vicia faba L.) in response to salinity in hydroponic and field experiments. Field Crop. Res. 2012, 127, 99-108.

68. Rathjen, A.H. The Response of Grain Legumes to Boron. Honours Thesis, The University of Adelaide, Adelaide, Australia, 1987.

69. Hall, A.E. Breeding for heat tolerance. Plant Breed. Rev. 1992, 10, 129-168.

70. Wahid, A.; Gelani, S.; Ashraf, M.; Foolad, M.R. Heat tolerance in plants: An overview. Env. Exp. Bot. 2007, 61, 199-223.

71. Arbaoui, M.; Balko, C.; Link, W. Study of faba bean (Vicia faba L.) winter-hardiness and development of screening methods. Field Crop. Res. 2008, 106, 60-67.

72. Inci, N.E.; Toker, C. Screening and selection of faba beans (Vicia faba L.) for cold tolerance and comparison to wild relatives. Genet. Resour. Crop Evol. 2011, 58, 1169-1175.

73. Nassar-Abbas, S.M. Investigation of Environmental Staining and Storage on Discolouration and Cooking Quality in Faba Bean (Vicia faba L.). Ph.D. Thesis, The University of Western Australia, Perth, Australia, 2007.

74. Larralde, J.; Martinez, J.A. Nutritional value of faba bean: Effects on nutrient utilization, protein turnover and immunity. Options Méditerr. 1991, 10, 111-117.

75. El-Sherbeeny, M.; Robertson, L.D. Protein content variation in a pure line faba bean (Vicia faba) collection. J. Sci. Food Agric. 2006, 58, 193-196.

76. Link, W. Methods and objectives in fababean breeding. In Proceedings of the International Workshop on Faba Bean Breeding and Agronomy, Córdoba, Spain, 25-27 October 2006; Junta de Andalucia: Córdoba, Spain, 2006; pp. 35-40.

77. Kuman, R.; Singh, M. Tannins: Their adverse role in ruman nutrition. J. Agric. Food Chem. 1984, 32, 447.

78. Bartolomé, B.; Quesada, C.; Gómez-Cordibés, C.; Hernandez, T.; Estrella, I. New contributions to the inhibition study of R-amylase and trypsin by phenolic compounds. In Bioactive Substances in Food of Plant Origin; Kozlowska, H., Fornal, J., Zdunczyk, Eds.; Polish Academy of Sciences: Olstyn, Poland, 1994; Volume 1, pp. 233-238.

79. Nelson, L.D.; Cox, M. Glycolysis, gluconeogenesis, and the pentose phosphate pathway. In Principles of Biochemistry; Freeman: New York, NY, USA, 2005; p. 551.

80. Moose, S.P.; Mumm, R.H. Molecular plant breeding as the foundation for 21 st century crop improvement. Plant Physiol. 2008, 147, 969-977.

81. Collard, B.C.; Mackill, D.J. Marker-assisted selection: An approach for precision plant breeding in the twenty-first century. Philos. Trans. Soc. Biol. Sci. 2008, 363, 557-572.

82. Johnson, G.R.; McCuddin, Z.P. Maize and the biotech industry. In Handbook of Maize: Its Biology; Bennetzen, J.L., Hake, S.C., Eds.; Springer: Berlin, Germany, 2009; pp. 115-140. 
83. Collard, B.C.Y.; Jahufer, M.Z.Z.; Brouwer, J.B.; Pang, E.C.K. An introduction to markers, quantitative trait loci (QTL) mapping and marker-assisted selection for crop improvement: The basic concepts. Euphytica 2005, 142, 169-196.

84. Torres, A.M.; Weeden, N.F.; Martin, A. Linkage among isozyme, RFLP and RAPD markers in Vicia faba. Theor. Appl. Genet. 1993, 85, 937-945.

85. Pozarkova, D.; Koblizkova, A.; Román, B.; Torres, A.M.; Lucretti, S.; Lysak, M.; Dolezel, J.; Macas, J. Development and characterization of microsatellite markers from chromosome 1-specific DNA libraries of Vicia faba. Biol. Plant. 2002, 45, 337-345.

86. Alghamdi, S.; Migdadi, H.; Ammar, M.; Paull, J.; Siddique, K.H.M. Faba bean genomics: Current status and future prospects. Euphytica 2012; doi:10.1007/s10681-012-0658-4.

87. Avila, C.M.; Sillero, J.C.; Rubiales, D.; Moreno, M.T.; Torres, A.M. Identification of RAPD markers linked to the $U v f-1$ gene conferring hypersensitive resistance against rust (Uromyces viciae-fabae) in Vicia faba L. Theor. Appl. Genet. 2003, 107, 353-358.

88. Roman, B.; Alfaro, C.; Torres, A.M.; Moreno, M.T.; Satovic, Z.; Pujadas, A.; Rubiales, D. Genetic relationships among Orobanche species as revealed by RAPD analysis. Ann. Bot. 2003, 91, 637-642.

89. Avila, C.M.; Satovic, Z.; Sillero, J.C.; Rubiales, D.; Moreno, M.T.; Torres, A.M. Isolate and organ-specific QTLs for ascochyta blight resistance in faba bean (Vicia faba L.). Theor. Appl. Genet. 2004, 108, 1071-1078.

90. Roman, B.; Satovic, Z.; Avila, C.M.; Rubiales, D.; Moreno, M.T.; Torres, A.M. Locating genes associated with Ascochyta fabae resistance in Vicia faba. Aust. J. Agric. Res. 2003, 54, 85-90.

91. Diaz-Ruiz, R.; Torres, A.M.; Satovic, Z.; Gutierrez, M.V.; Cubero, J.I.; Roman, B. Validation of QTLs for Orobanche crenata resistance in faba bean (Vicia faba L.) across environments and generations. Theor. Appl. Genet. 2010, 120, 909-919.

92. Satovic, Z.; Avila, C.; Palomino, C.; Vitale, S.; Gutierrez, N.; Cruz-Izquierdo, S.; Gutierrez, M.V.; Ruiz, M.D.; Ocaña, S.; Torres, A.M. Towards a unified and functional consensus linkage map in faba bean (Vicia faba L.). Candidate Gene Identification and Breeding Applications, 2012.

93. Díaz-Ruiz, R.; Satovic, Z.; Avila, C.M.; Alfaro, C.M.; Gutierrez, M.V.; Torres, A.M.; Román, B. Confirmation of QTLs controlling Ascochyta fabae resistance in different generations of faba bean (Vicia faba L.). Crop Pasture Sci. 2009, 60, 353-361.

94. Lander, E.; Kruglyak, L. Genetic dissection of complex traits: Guidelines for interpreting and reporting linkage results. Nat. Genet. 1995, 11, 241-247.

95. Sillero, J.C.; Fondevilla, S.; Davidson, J.; Vaz Patto, M.C.; Warkentin, T.; Thomas, J.; Rubiales, D. Screening techniques and sources of resistance to rusts and mildews in grain legumes. Euphytica 2006, 147, 255-272.

96. Duvick, D.N. Plant breeding, an evolutionary concept. Crop Sci. 1996, 36, 539-548.

97. Roman, B.; Satovic, Z.; Rubiales, D.; Torres, A.M.; Cubero, J.I.; Katzir, N.; Joel, D.M. Variation among and within populations of the parasitic weed Orobanche crenata from Spain and Israel revealed by Inter Simple Sequence Repeat markers. Phytopathology 2002, 92, 1262-1266. 
98. Nassib, A.M.; Ibrahim, A.A.; Khalil, S.A. Breeding for resistance to Orobanche. In Faba Bean Improvement; Hawtin, G., Webb, C., Eds.; Martinus Nijhoff: Hague, The Netherlands, 1982; pp. 199-206.

99. Cubero, J.I.; Moreno, M.T.; Hernández, L. A faba bean (Vicia faba L.) cultivar resistant to broomrape (Orobanche crenata Forsk.). In Proceedings of the First Europe Conference on Grain Legumes; Angers, F., Ed.; Association Europeenne des Protéagineux: Paris, France, 1992; pp. $41-42$.

100. Austin, D.F.; Lee, M. Comparative mapping in $\mathrm{F}_{2: 3}$ and $\mathrm{F}_{6: 7}$ generations of quantitative trait loci for grain yield and yield components in maize. Theor. Appl. Genet. 1996, 92, 817-826.

101. Duc, G.; Sixdenier, G.; Lila, M.; Furstoss, V. Search of Genetic Variability for Vicine and Convicine Content in Vicia faba L. A first report of a gene which codes for nearly zero-vicine and zero-convicine contents. In Recent Advances of Research in Antinutritional Factors in Legume Seeds; Huisman, J., van der Poel, A.F.B., Liener, I.E., Eds.; Pudoc: Wageningen, The Netherlands, 1989; pp. 305-313.

102. Gutierrez, N.; Avila, C.M.; Duc, G.; Marget, P.; Suso, M.J.; Moreno, M.T.; Torres, A.M. CAPs markers to assist selection for low vicine and convicine contents in faba bean (Vicia faba L.). Theor. Appl. Genet. 2006, 114, 59-66.

103. Cabrera, A.; Martin, A. Variation in tannin content in Vicia faba L. J. Agric. Sci. 1986, 106, $377-382$.

104. Duc, G.; Marget, P.; Esnault, R.; Le Guen, J.; Bastianelli, D. Genetic variability for feeding value of faba bean seeds (Vicia faba): Comparative chemical composition of isogenics involving zerotannin and zero-vicine genes. J. Agric. Sci. 1999, 133, 185-196.

105. Varshney, R.K.; Close, T.J.; Singh, N.K.; Hoisington, D.A.; Cook, D.R. Orphan legume crops enter the genomics era! Curr. Opin. Plant. Biol. 2009, 12, 202-210.

106. Kaur, S.; Cogan, N.O.; Pembleton, L.W.; Shinozuka, M.; Savin, K.W.; Materne, M.; Forster, J.W. Transcriptome sequencing of lentil based on second-generation technology permits large-scale unigene assembly and SSR marker discovery. BMC Genomics 2011, 12, 265.

107. Kaur, S.; Pembleton, L.; Cogan, N.; Savin, K.; Leonforte, T.; Paull, J.; Materne, M.; Forster, J. Transcriptome sequencing of field pea and faba bean for discovery and validation of SSR genetic markers. BMC Genomics 2012, 13, 104.

108. Sato, S.; Nakamura, Y.; Asamizu, E.; Isobe, S.; Tabata, S. Genome sequencing and genome resources in model legumes. Plant Physiol. 2007, 144, 588-593.

109. Sandal, N.; Petersen, T.R.; Murray, J.; Umehara, Y.; Karas, B.; Yano, K.; Kumagai, H.; Yoshikawa, M.; Saito, K.; Hayashi, M.; et al. Genetics of symbiosis in Lotus japonicus: Recombinant inbred lines, comparative genetic maps, and map position of 35 symbiotic loci. Mol. Plant Microbe Interact. 2006, 19, 80-91.

110. Choi, H.-K.; Mun, J.-H.; Kim, D.-J.; Zhu, H.; Baek, J.-M.; Mudge, J.; Roe, B.; Ellis, N.; Doyle, J.; Kiss, G.B.; et al. Estimating genome conservation between crop and model legume species. Proc. Natl. Acad. Sci. USA 2004, 101, 15289-15294.

111. Wang, X.; Sato, S.; Tabata, S.; Kawasaki, S. A high-density linkage map of Lotus japonicus based on AFLP and SSR markers. DNA Res. 2008, 15, 323-332. 
112. Gallardo, K.; Firnhaber, C.; Zuber, H.; Hericher, D.; Belghazi, M.; Henry, C.; Kuster, H.; Thompson, R. A combined proteome and transcriptome analysis of developing Medicago truncatula seeds: evidence for metabolic specialization of maternal and filial tissues. Mol. Cell Proteomics 2007, 6, 2165-2179.

113. Sanchez, D.H.; Lippold, F.; Redestig, H.; Hannah, M.A.; Erban, A.; Kramer, U.; Kopka, J.; Udvardi, M.K. Integrative functional genomics of salt acclimatization in the model legume Lotus japonicus. Plant J. 2008, 53, 973-987.

114. Watson, B.S.; Asirvatham, V.S.; Wang, L.; Sumner, L.W. Mapping the proteome of barrel medic (Medicago truncatula). Plant Physiol. 2003, 131, 1104-1123.

115. Gonzales, M.D.; Archuleta, E.; Farmer, A.; Gajendran, K.; Grant, D.; Shoemaker, R.; Beavis, W.D.; Waugh, M.E. The Legume Information System (LIS): an integrated information resource for comparative legume biology. Nucleic Acids Res. 2005, 33, D660-D665.

116. Rispail, N.; Péter, K.; Kiss, G.B.; Ellis, T.H.N.; Gallardo, K.; Thompson, R.D.; Prats, E.; Larrainzar, E.; Ladrera, R.; González, E.M.; et al. Model legumes contribute to faba bean breeding. Field Crops Res. 2010, 115, 253-269.

117. Kaló, P.; Endre, G.; Zimányi, L.; Csanádi, G.; Kiss, G.B. Construction of an improved linkage map of diploid alfalfa (Medicago sativa). Theor. Appl. Genet. 2000, 100, 641-657.

118. Cannon, S.B.; Sterck, L.; Rombauts, S.; Sato, S.; Cheung, F.; Gouzy, J.; Wang, X.; Mudge, J.; Vasdewani, J.; Schiex, T.; et al. Legume genome evolution viewed through the Medicago truncatula and Lotus japonicus genomes. Proc. Natl. Acad. Sci. USA 2006, 103, 14959-14964.

119. Phan, H.T.; Ellwood, S.R.; Hane, J.K.; Ford, R.; Materne, M.; Oliver, R.P. Extensive macrosynteny between Medicago truncatula and Lens culinaris ssp. culinaris. Theor. Appl. Genet. 2007, 114, 549-558.

120. Roman, B.; Satovic, Z.; Pozarkova, D.; Macas, J.; Dolezel, J.; Cubero, J.I.; Torres, A.M. Development of a composite map in Vicia faba, breeding applications and future prospects. Theor. Appl. Genet. 2004, 108, 1079-1088.

121. Schmutz, J.; Cannon, S.B.; Schlueter, J.; Ma, J.; Mitros, T.; Nelson, W.; Hyten, D.L.; Song, Q.; Thelen, J.J.; Cheng, J.; et al. Genome sequence of the palaeopolyploid soybean. Nature 2010, $463,178-183$.

122. Chen, Y.-L.; Huang, R.; Xiao, Y.-M.; Lu, P.; Chen, J.; Wang, X.-C. Extracellular calmodulin-induced stomatal closure is mediated by heterotrimeric $\mathrm{G}$ protein and $\mathrm{H}_{2} \mathrm{O}_{2}$. Plant Physiol. 2004, 136, 4096-4103.

123. Gao, X.Q.; Li, C.G.; Wei, P.C.; Zhang, X.Y.; Chen, J.; Wang, X.C. The dynamic changes of tonoplasts in guard cells are important for stomatal movement in Vicia faba. Plant Physiol. 2005, 139, 1207-1216.

124. Perlick, A.M.; Frühling, M.; Schröder, G.; Frosch, S.C.; Pühler, A. The broad bean gene VfNOD32 encodes a nodulin with sequence similarities to chitinases that is homologous to (alpha/beta) 8-barrel-type seed proteins. Plant Physiol. 1996, 110, 147-154.

125. Hanstein, S.M.; Felle, H.H. $\mathrm{CO}_{2}$-triggered chloride release from guard cells in intact fava bean leaves. Kinetics of the onset of stomatal closure. Plant Physiol. 2002, 130, 940-950.

126. Li, J.; Assmann, S.M. An abscisic acid-activated and calcium-independent protein kinase from guard cells of fava bean. Plant Cell 1996, 8, 2359-2368. 
127. Iwai, S.; Shimomura, N.; Nakashima, A.; Etoh, T. New fava bean guard cell signaling mutant impaired in ABA-induced stomatal closure. Plant Cell Physiol. 2003, 44, 909-913.

128. Miranda, M.; Borisjuk, L.; Tewes, A.; Heim, U.; Sauer, N.; Wobus, U.; Weber, H. Amino acid permeases in developing seeds of Vicia faba L.: Expression precedes storage protein synthesis and is regulated by amino acid supply. Plant $J$. 2001, 28, 61-71.

129. Horstmann, C.; Schlesier, B.; Otto, A.; Kostka, S.; Müntz, K. Polymorphism of legumin subunits from field bean (Vicia faba L. var. minor) and its relation to the corresponding multigene family. Theor. Appl. Genet. 1993, 86, 867-874.

130. Weschke, W.; Bassüner, R.; Van Hai, N.; Czihal, A.; Baümlein, H.; Wobus, U. The structure of a Vicia faba vicilin gene. Biochem. Physiol. Pflanzen. 1988, 183, 233-242.

131. Tucci, M.; Capparelli, R.; Costa, A.; Rao, R. Molecular heterogeneity and genetics of Vicia faba seed storage proteins. Theor. Appl. Genet. 1991, 81, 50-58.

132. Knaak, C.; Roskothen, P.; Roebbelen, G. Symbiotic efficiency of Vicia faba genotypes after field inoculation with different strains of Rhizobium leguminosarum preselected in greenhouse tests. J. Plant Physiol. 1993, 141, 49-53.

133. Hohnjec, N.; Küster, H.; Albus, U.; Frosch, S.C.; Becker, J.D.; Pühler, A.; Perlick, A.M.; Frühling, M. The broad bean nodulin VfENOD18 is a member of a novel family of plant proteins with homologies to the bacterial MJ0577 superfamily. Mol. Gen. Genet. 2000, 264, 241-250.

134. Perlick, A.M.; Pühler, A. A survey of transcripts expressed specifically in root nodules of broadbean (Vicia faba L.). Plant Mol. Biol. 1993, 22, 957-970.

135. Küster, H.; Frühling, M.; Perlick, A.M.; Pühler, A. The sucrose synthase gene is predominantly expressed in the root nodule tissue of Vicia faba. Mol Plant Microbe Interact. 1993, 6, 507-514.

136. Schroder, G.; Fruhling, M.; Puhler, A.; Perlick, A.M. The temporal and spatial transcription pattern in root nodules of Vicia faba nodulin genes encoding glycine-rich proteins. Plant Mol. Biol. 1997, 33, 113-123.

137. Fehlberg, V.; Vieweg, M.F.; Dohmann, E.M.; Hohnjec, N.; Puhler, A.; Perlick, A.M.; Kuster, H. The promoter of the leghaemoglobin gene VfLb29: Functional analysis and identification of modules necessary for its activation in the infected cells of root nodules and in the arbuscule-containing cells of mycorrhizal roots. J. Exp. Bot. 2005, 56, 799-806.

138. Frühling, M.; Roussel, H.; Gianinazzi-Pearson, V.; Pühler, A.; Perlick, A.M. The Vicia faba leghemoglobin gene VfLb29 is induced in root nodules and in roots colonized by the arbuscular mycorrhizal fungus Glomus fasciculatum. Mol. Plant. Microbe Interact. 1997, 10, 124-131.

139. Vieweg, M.F.; Frühling, M.; Quandt, H.J.; Heim, U.; Bäumlein, H.; Pühler, A.; Küster, H.; Andreas, M.P. The promoter of the Vicia faba L. leghemoglobin gene VfLb29 is specifically activated in the infected cells of root nodules and in the arbuscule-containing cells of mycorrhizal roots from different legume and nonlegume plants. Mol. Plant Microbe Interact. 2004, 17, 6269.

140. Pickersgill, B.; Jones, J.K.; Ramsay, G.; Stewart, H. Problems and prospects of wild crossing in the genus Vicia for the improvement of faba bean. In Proceedings of the International Worshop on Faba beans, Kabuli Chickpeas and Lentil in the 1980s, Aleppo, Syria, 16-20 May 1983; Saxena, M.C., Varma, S., Eds.; ICARDA: Aleppo, Syria, 1983. 
141. Ramsay, G.; Pickersgill, B.; Jones, J.K.; Hammond, L.; Stewart, M.H. Barriers to interspecific hybridization between $V$. faba and other species of section Faba. In Vicia faba: Agronomy, Physiology and Breeding; Hebblethwaite, P.D., Dawkins, T.C.K., Heath, M.C., Lockwood, G., Eds.; Martinus Nijhoff: Hague, The Netherlands, 1984; pp. 201-208.

142. Ladizinsky, G.; Pickersgill, B.; Yamamoto, K. Exploitation of wild relatives of the food legumes. In World Crops: Cool Season Food Legumes; Summerfield, R.J., Ed.; Kluwer Academic Press: Dordrecht, The Netherlands, 1988; p. 967.

143. Venketeswaran, S. Tissue culture studies on Vicia faba L. Establishment of culture. Phytomorphology 1962, 12, 300-306.

144. Grant, M.; Fuller, K.W. Tissue culture of root cells of Vicia faba. J. Exp. Bot. 1968, 19, 667-680.

145. Mitchell, J.P.; Gildow, F.E. The initiation and maintenance of Vicia faba tissue cultures. Physiol. Plant. 1975, 34, 250-253.

146. Röper, W. Growth and cytology of callus and cell suspension cultures of Vicia faba L. Z. Pflanzenphysiol. 1979, 93, 245-257.

147. Bieri, V.; Schmid, J.; Keller, E.R. Shoot tip culture in Vicia faba L. In Efficiency in Plant Breeding: Proceedings of the 10th Congress of the European Association for Research on Plant Breeding, Wageningen, Netherlands, 19-24 June 1983; Lange, W., Zeven, A.C., Hogenboom, N.F., Eds.; EUCARPIA: Wageningen, The Netherlands, 1984; p. 295.

148. Selva, E.; Stouffs, M.; Briquet, M. In vitro propagation of Vicia faba L. by micro-cutting and multiple shoot induction. Plant Cell Tiss. Org. Cult. 1989, 18, 167-179.

149. Thynn, M.; Werner, D. Plantlet regeneration and somatic differentiation in faba bean (Vicia faba L.) from callus culture of various explants. Angewandte Botanik 1987, 61, 483-492.

150. Binding, H.; Nehls, R. Regeneration of isolated protoplasts of Vicia faba L. Z. Pflanzenphysiol. 1978a, 88, 327-332.

151. Binding, H.; Nehls, R. Somatic cell hybridization of Vicia faba and Petunia hybrida. Mol. Gen. Genet. 1978, 164, 137-143.

152. Röper, W. Callus formation from protoplasts derived from cell suspension cultures of Vicia faba L. . Z. Pflanzenphysiol. 1981, 101, 75-78.

153. Tegeder, M.; Gebhardt, D.; Schieder, O.; Pickardt, T. Thidiazuron-induced plant regeneration from protoplasts of Vicia faba cv. Mythos. Plant Cell Rep. 1995, 15, 164-169.

154. Griga, M.; Kubalakova, M.; Tejklova, E. Somatic embryogenesis in Vicia faba L. Plant Cell Tiss. Org. Cult. 1987, 9, 167-171.

155. Pickardt, T.; Huancaruna Perales, E.; Schieder, O. Plant regeneration via somatic embryogenesis in Vicia narbonensis. Protoplasma 1989, 149, 5-10.

156. Pickardt, T.; Meixner, M.; Schade, V.; Schieder, O. Transformation of Vicia narbonensis via Agrobacterium tumefaciens-mediated gene transfer. Plant Cell Rep. 1991, 9, 535-538.

157. Jelenic, S.; Mitrikeski, P.T.; Papes, D.; Jelaska, S. Agrobacterium-mediated transformation of broad bean Vicia faba L. Food Technol. Biotech. 2000, 38, 167-172.

158. Siefkes-Boer, H.J.; Noonan, M.J.; Bullock, D.W.; Conner, A.J. Hairy root transformation system in large- seeded grain legumes. Israel J. Plant Sci. 1995, 43, 1-5. 
159. Saalbach, I.; Pickardt, T.; Machemehl, F.; Saalbach, G.; Schieder, O.; Müntz, K. A chimeric gene encoding the methionine-rich 2S albumin of Brazil nut (Bertholletia excelsa H.B.K.) is stably expressed and inherited in transgenic grain legumes. Mol. Gen. Genet. 1994, 242, 226-236.

160. Schiemann, J.; Eisenreich, G. Transformation of field bean Vicia faba L. cells expression of a chimeric gene in cultured hairy roots and root-derived callus. Biochem. Physiol. Pflanzen. 1989, $185,135-140$.

161. Ramsay, G.; Kumar, A. Transformation of Vicia faba cotyledon and stem tissues by Agrobacterium rhizogenes - Infectivity and cytological studies. J. Exp. Bot. 1990, 41, 841-847.

162. Böttinger, P.; Steinmetz, A.; Schieder, O.; Pickardt, T. Agrobacterium-mediated transformation of Vicia faba. Mol. Breed. 2001, 8, 243-254.

163. Hanafy, M.; Pickardt, T.; Kiesecker, H.; Jacobsen, H.-J. Agrobacterium-mediated transformation of faba bean (Vicia faba L.) using embryo axes. Euphytica 2005, 142, 227-236.

164. Cubero, J.I.; Nadal, S. Faba bean (Vicia faba L.). In Genetic Resources, Chromosome Engineering, and Crop Improvement for Grain legumes; Singh, R.J., Jauhar, P., Eds.; CRC Press, Taylor \& Francis Group: Boca Raton, FL, USA, 2005; p. 163.

165. Palomino, C.; Satovic, Z.; Cubero, J.I.; Torres, A.M. Identification and characterization of NBS-LRR class resistance gene analogs in faba bean (Vicia faba L.) and chickpea (Cicer arietinum L.). Genome 2006, 49, 1227-1237.

166. Palomino, C.; Fernandez-Romero, M.D.; Rubio, J.; Torres, A.M.; Moreno, M.T.; Millán, T. Integration of new CAPS and dCAPS-RGA markers into a composite chickpea genetic map and their association with disease resistance. Theor. Appl. Genet. 2008, 118, 671-682.

167. Grain Legumes Integrated Project (GLIP). Available online: http://www.eugrainlegumes.org/ (accessed on 13 January 2012).

168. Mardis, E.R. The impact of next-generation sequencing technology on genetics. Trends Genet. 2008, 24, 133-141.

169. Morozova, O.; Marra, M.A. Applications of next-generation sequencing technologies in functional genomics. Genomics 2008, 92, 255-264.

170. Huang, X.; Wei, X.; Sang, T.; Zhao, Q.; Feng, Q.; Zhao, Y.; Li, C.; Zhu, C.; Lu, T.; Zhang, Z.; et al. Genome-wide association studies of 14 agronomic traits in rice landraces. Nat. Genet. 2010, 42, 961-967.

171. Lam, H.-M.; Xu, X.; Liu, X.; Chen, W.; Yang, G.; Wong, F.-L.; Li, M.-W.; He, W.; Qin, N.; Wang, B.; et al. Resequencing of 31 wild and cultivated soybean genomes identifies patterns of genetic diversity and selection. Nat. Genet. 2010, 42, 1053-1059.

172. Dwivedi, S.L.; Crouch, J.H.; Mackill, D.J.; Xu, Y.; Blair, M.W.; Ragot, M.; Upadhyaya, H.D.; Ortiz, R. The molecularization of public sector crop breeding: Progress, problems, and prospects. Adv. Agron. 2007, 95, 163-318.

173. Exploiting Genetic Variability of Resistance Genes in Major European Food Legumes to Improve Varieties For Sustainable Agriculture; ERA-PG Funded Project; GENXPro GmbH: Frankfurt, Germany, 2010 Available online: http://www.erapg.org/publicitem.m?key=everyone\& pgid=19083\&trail=/everyone/16790/18613/18624/19083. (accessed on 12 March 2012). 
174. Kahl, G.; Winter, P.; Horres, R.; Rotter, B.; Jüngling, R.; Consortium, L. Pathogenesis-related genes and genetic variation in potential resistance genes of major European legumes: The LEGRESIST project. In Ascochyta 2009: Proceedings of the Second International Ascochyta Workshop, Pullman, WA, USA, 28 June-2 July 2009; p. 47.

175. Goodman, M.M. Plant breeding requirements for applied molecular biology. Crop Sci. 2004, 44, 1913-1914.

(C) 2012 by the authors; licensee MDPI, Basel, Switzerland. This article is an open access article distributed under the terms and conditions of the Creative Commons Attribution license (http://creativecommons.org/licenses/by/3.0/). 